\title{
1. PETROLOGY OF HYDROTHERMAL MINERALIZATION: A VERTICAL SECTION THROUGH THE TAG MOUND ${ }^{1}$
}

\author{
Richard Knott, ${ }^{2}$ Yves Fouquet, ${ }^{3}$ José Honnorez, ${ }^{2}$ Sven Petersen, ${ }^{4}$ and Marcel Bohn ${ }^{3}$
}

\begin{abstract}
Mineralogical, textural, chemical, and isotopic features of a vertical section through the active Trans-Atlantic Geotraverse (TAG) hydrothermal mound reveal the nature of subsurface mineralization. The multistage growth and evolution of the TAG mound occurs by the following processes: (1) near-surface ( $<10 \mathrm{~m}$ depth) hydrothermal precipitation of porous $\mathrm{Fe}-\mathrm{Cu}-\mathrm{Zn}$ sulfide and Si-Fe-oxyhydroxides; (2) modification of surface material within the mound ( $>20 \mathrm{~m}$ depth) by sequential overgrowth, recrystallization and mineral dissolution; (3) hydrothermal mineralization within the mound, forming Fe-Cu sulfides, anhydrite and quartz; and (4) alteration and mineralization of basalt basement beneath the mound. During the long history of hydrothermal activity, these processes have driven the TAG mound toward a mineralogy dominated by pyrite and depleted in $\mathrm{Cu}, \mathrm{Zn}$, and trace elements. The basement beneath the mound is ultimately altered to pyrite-quartz.

Sulfur-isotope composition of sulfides in the range $+4.4 \%$ o to $+8.9 \%$ o requires a deep hydrothermal source with elevated $\delta^{34} \mathrm{~S}$ to generate an end-member fluid with estimated $\delta^{34} \mathrm{~S}$ of $+5.5 \%$. Vein-related sulfide mineralization is isotopically light, whereas sulfide disseminated in altered basalt is isotopically heavy. The systematic variations between sulfide generations and a general increase with depth are a result of sulfate reduction in a shallow seawater-hydrothermal circulation system developed around the hydrothermal feeder zone. This generates hydrothermal fluid and sulfide mineralization with a maximum $\delta^{34} \mathrm{~S}$ of $+8.9 \%$. Mixing between this shallow circulated fluid and the end-member hydrothermal component would explain the variations of up to $3 \%$ observed between different sulfide generations in the mound.
\end{abstract}

\section{INTRODUCTION}

Black smoker chimneys are the spectacular, short-lived manifestation of focused high-temperature submarine hydrothermal activity at mid-ocean ridges. A chimney typically remains active for only a few hundred years. During this activity only a small proportion of the total mass flux of dissolved metals, sulfide, and silica is precipitated in the chimney: most of the mass flux is lost to the ocean in the hydrothermal plume. Once the chimney becomes inactive it will collapse through the actions of weathering and mass wasting. Subsurface mineralization related to more diffuse hydrothermal upflow is probably a more efficient process, because of restricted mixing, dilution, and cooling by interaction with seawater. Subsurface mineralizing processes have the potential to form large mound and stockwork massive sulfide deposits analogous to those preserved on land. Recently formed submarine hydrothermal deposits (i.e., those less than a few thousand years old) show considerable divergence in morphology, texture, mineralogy, and geochemistry, both between each other (e.g., Fouquet et al., 1993; Graham et al., 1988; Koski et al., 1994) and with their ancient volcanogenic massive sulfide (VMS) analogues (e.g., Oudin et al., 1981). Many of the petrologic characteristics of ancient deposits are interpreted to be derived from subseafloor hydrothermal processes superimposed on primary hydrothermal precipitates. Only a small number of known seafloor deposits are large and mature enough for this hypothesis to be tested; the TAG hydrothermal mound at $26^{\circ} \mathrm{N}$ on the Mid-Atlantic Ridge is one such deposit. Other deposits of similar character have been described by Fouquet et al. (1988, in press) at the Marginal High and Southeast Seamount, East Pacific Rise (EPR) $13^{\circ} \mathrm{N}$; by Alt (1988) at the Green

${ }^{1}$ Herzig, P.M., Humphris, S.E., Miller, D.J., and Zierenberg, R.A. (Eds.), 1998. Proc. ODP, Sci. Results, 158: College Station, TX (Ocean Drilling Program).

${ }^{2}$ Institut de Géologie, Université Louis Pasteur, 1 rue Blessig, Strasbourg 67084 Cedex, France.rknott@globalnet.co.uk

${ }^{3}$ IFREMER, Centre de Brest, DRO/GM BP 70, 29280 Plouzane, France.

${ }^{4}$ Lehrstuhl für Lagerstättenlehre, Institut für Mineralogie, Technische Universität Bergakademie Freiberg, Brennhausgasse 14, D-09596 Freiberg, Federal Republic of Germany.
Seamount, EPR $21^{\circ} \mathrm{N}$; by Scott et al. (1990) from the southern Explorer Ridge; and by Embley et al. (1988) from the Galapagos Rift.

The TAG hydrothermal mound is important because of its large size, hydrothermal activity, and long history of mineralization. Surface sampling of hydrothermal fluids and substrate provides evidence for internal mineralizing and alteration processes (e.g., Edmond et al., 1995; Tivey et al., 1995). Core drilled from the massive sulfide mound and underlying altered basement during Leg 158 of the Ocean Drilling Program (ODP) represent the first samples recovered from beneath the surface of an active hydrothermal system on a sedimentfree ridge (Humphris et al., 1995; Humphris, Herzig, Miller, et al., 1996). Here we describe the mineralogy, textures, sulfide geochemistry, and sulfur-isotope composition of hydrothermal mineralization in four vertical sections through the TAG mound, and examine the processes of surface deposition, subsurface deposition, and postdeposition modification during the evolution of the hydrothermal mound. Bulk geochemistry of a subset of the samples described here is reported by Fouquet et al. (Chap. 27, this volume).

Experimental and theoretical approaches provide a conceptual model for the isotope systematic of sulfur in mid-ocean ridge hydrothermal systems (Shanks et al., 1981; Janecky and Shanks, 1988; Bowers, 1989). The applicability of this model has been tested by sulfur-isotopic studies of active surface hydrothermal deposits and vent fluids (e.g., Shanks and Seyfried, 1987; Bluth and Ohmoto, 1988; Woodruff and Shanks, 1988), by the characterization of sulfur geochemistry and isotopic variation in a section of old ocean crust (Alt et al., 1989), and by comparable studies of the fossil hydrothermal system in an ophiolite (Alt, 1994). Sulfur-isotope data from samples of the subsurface TAG mound and underlying stockwork feeder system provide the first possibility to examine the connection between surface deposit-scale and crustal-scale observations.

\section{Geological Setting}

The TAG hydrothermal field is spread over a $5 \mathrm{~km} \times 5 \mathrm{~km}$ area of the median valley of the Mid-Atlantic Ridge, close to the eastern wall

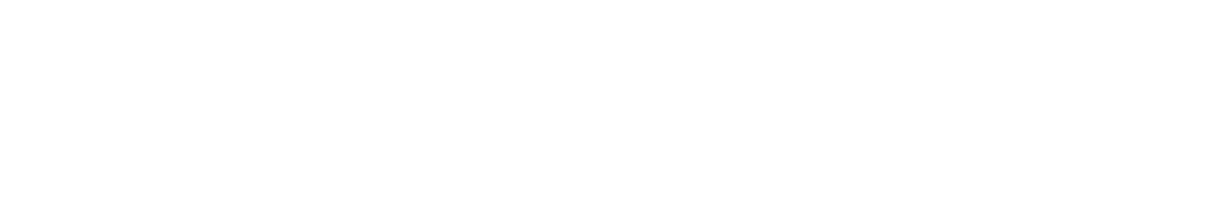


(Fig. 1). There are three major hydrothermal features: a zone of lowtemperature $\mathrm{Mn}$ - and $\mathrm{Fe}$ - oxide and nontronite, high on the median valley wall (Thompson et al., 1985), relict massive sulfide mounds (the Mir and Alvin zones; Rona et al., 1993a), and the TAG active hydrothermal mound.

The geological setting and surface geology of the TAG active hydrothermal mound have been previously described based on a number of remote sensing and submersible studies (e.g., Thompson et al., 1988; Rona et al., 1993b; Tivey et al., 1995; Kleinrock et al., 1996). The results of these studies are briefly summarized here. The TAG active mound is located about $2.5 \mathrm{~km}$ east of the neovolcanic zone (Fig. 1) in a water depth of about $3670 \mathrm{~m}$. The seafloor in the area is composed of pillow lavas covered by pelagic calcareous sediments and is dissected by axis-parallel fissures and oblique faults (Kleinrock et al., 1996).

The mound is a circular structure, $200 \mathrm{~m}$ in diameter, with a maximum relief of $50 \mathrm{~m}$ above the surrounding seafloor (Fig. 2). It is steep-sided and topped by two relatively flat terraces, at depths of 3642-3648 $\mathrm{m}$ and 3650-3654 $\mathrm{m}$ (Kleinrock et al., 1996). Hightemperature, black smoker activity is asymmetrically focused on the upper terrace $25 \mathrm{~m}$ northwest of the center of the mound. The black smoker complex is a conical structure 40 to $50 \mathrm{~m}$ in basal diameter and 10 to $20 \mathrm{~m}$ tall, topped by a cluster of chalcopyrite-anhydrite chimneys where hydrothermal fluids are vigorously venting at temperatures of $360^{\circ}-366^{\circ} \mathrm{C}$; (Edmond et al., 1995). The temperature and chemistry of these fluids have remained constant over at least 4 years (Edmond et al., 1995). Small fissures or cavities between blocks of sulfide show diffuse venting of clear shimmering fluids or wispy black smoke. On the lower terrace, $70 \mathrm{~m}$ southeast of the black smoker complex is the Kremlin area. Less vigorous, lower temperature $\left(273^{\circ}-301^{\circ} \mathrm{C}\right.$; Edmond et al., 1995) white smoker venting forms a group of small, dome-like sphalerite-silica chimney structures. The temperature and chemistry of the white smoker fluids indicate that they evolved from an end-member black smoker vent fluid composition within the mound by conductive cooling and mixing with entrained seawater (Edmond et al., 1995; Tivey et al., 1995). These physical processes were accompanied by precipitation of $\mathrm{Fe}-\mathrm{Cu}$ sulfides, precipitation of anhydrite, and dissolution of sphalerite within the mound (Edmond et al., 1995; Tivey et al., 1995).

The mound surface is entirely composed of hydrothermal precipitates, in the form of poorly sorted blocks of massive sulfide and sediments composed of Si-Fe oxyhydroxide (Tivey et al., 1995). Platelike crusts of massive sulfide and corroded massive anhydrite occur close to the black smoker complex; elsewhere, porous mound sulfides form bulbous blocks. The steep western, northern, and eastern sides of the mound are composed of sulfide talus; rare fragments of hydrothermally altered basalt were found in a debris flow on the northeastern flank (Masuda et al., 1995). Heat flow is variable and locally very high over most of the mound surface (Becker and Von Herzen, 1996). Radiometric dating of hydrothermal samples indicates that the active TAG mound has been episodically active for at least 20,000 yr (Lalou et al., 1990, 1993).

\section{Site 957}

The TAG hydrothermal mound was drilled in October and November 1994 during Leg 158 (Humphris et al., 1995; Humphris, Herzig, Miller, et al., 1996). Cores were recovered from 15 holes on the TAG mound drilled to depths of between 9 and 125.7 meters below seafloor (mbsf). These holes were concentrated in five areas of the mound, designated TAG-1 through -5 (Fig. 2). For the purpose of this paper we combine cores from the multiple holes in each area to form composite sections for each area. This is justified because the offset between holes in an single area was generally $10 \mathrm{~m}$ or less. The drilling results are summarized in Table 1 . Because of the generally low recovery, all descriptions and interpretations assume that the material recovered is representative of the actual composition and zona-

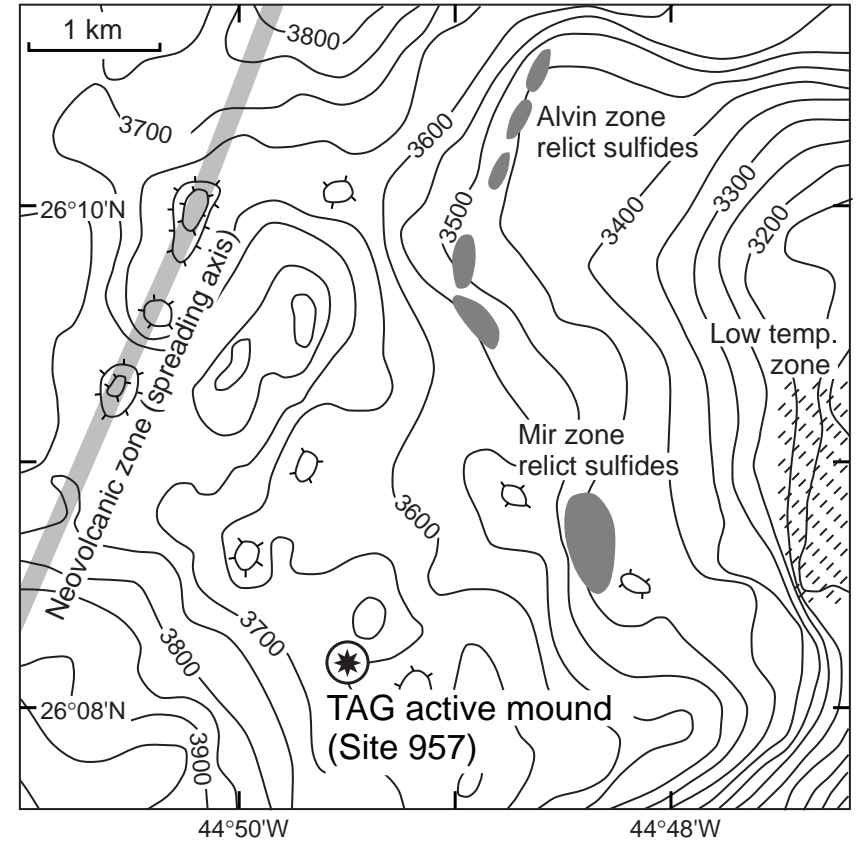

Figure 1. The TAG hydrothermal field, showing locations of the TAG active hydrothermal mound (Site 957), Alvin and Mir relict hydrothermal zones, low-temperature hydrothermal zone on the eastern rift valley wall, and volcanic domes that define the neovolcanic zone of the ridge axis (50-m isobaths). Modified from Rona et al. (1993b).

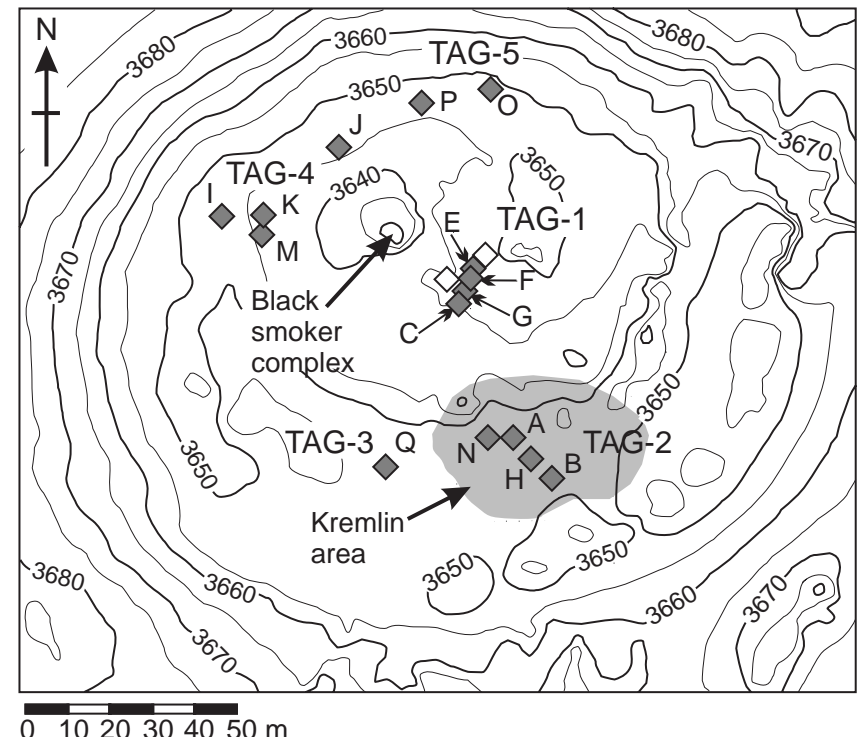

Figure 2. High-resolution bathymetry of the active TAG hydrothermal mound (5-m isobaths). Cores were recovered from holes drilled in 5 areas, referred to as TAG-1 through TAG-5. Modified from Humphris, Herzig, Miller, et al. (1996).

tion of the mound. Depths are quoted as meters below seafloor relative to the mound surface. The mound surface is at the same level for sites TAG-1, -4 , and -5 on the upper terrace (at about $3645 \mathrm{~m}$ water depth); TAG-2 on the lower terrace is about $7 \mathrm{~m}$ lower, at a water depth of $3652 \mathrm{~m}$.

TAG-1 is close to the center of the mound about $20 \mathrm{~m}$ from the black smoker complex. Surface hydrothermal precipitates in this area are composed of porous blocks of $\mathrm{Fe}-\mathrm{Zn}$ and $\mathrm{Fe}-\mathrm{Cu}$ sulfide mineralization (Tivey at al., 1995). Closer to the black smoker complex, 
Table 1. Summary of core recovery from Site 957.

\begin{tabular}{|c|c|c|c|}
\hline Hole & $\begin{array}{l}\text { Cored interval } \\
\quad(\mathrm{mbsf})\end{array}$ & $\begin{array}{l}\text { Recovery } \\
\quad(\%)\end{array}$ & Lithology \\
\hline \multicolumn{4}{|c|}{ TAG-1 (Central) Upper terrace, $20 \mathrm{~m}$ southeast of black smoker complex, $3645 \mathrm{~m}$ depth. } \\
\hline $957 \mathrm{C}$ & $0.0-49.2$ & 44.1 & Massive sulfide, sulfide-anhydrite, sulfide-quartz, silicified basalt \\
\hline 957E & $31.5-125.7$ & 4.3 & Massive sulfide, sulfide-quartz, silicified basalt, argillized basalt \\
\hline $957 \mathrm{~F}$ & $1.0-10.0$ & 10.5 & Massive (porous) sulfide, sulfide-anhydrite \\
\hline $957 \mathrm{G}$ & $12.0-25.0$ & 8.6 & Massive sulfide, sulfide-anhydrite \\
\hline \multicolumn{4}{|c|}{ TAG-2 (Kremlin) Lower terrace, Kremlin area, $3652 \mathrm{~m}$ depth. } \\
\hline 957A & $0.0-15.0$ & 1.7 & Si-Fe oxyhydroxide, massive (porous) sulfide \\
\hline 957B & $0.0-29.6$ & 5.6 & Fe-oxide drill cuttings, $\mathrm{Si}-\mathrm{Fe}$ oxyhydroxide, massive sulfide, basalt (slightly altered) \\
\hline $957 \mathrm{H}$ & $8.7-54.5$ & 10.9 & Si-Fe oxyhydroxide, massive sulfide, sulfide-anhydrite, sulfide-quartz, silicified basalt \\
\hline $957 \mathrm{~N}$ & $0.0-42.2$ & 1.0 & Si-Fe oxyhydroxide, sulfide-anhydrite, sulfide-quartz (wash core) \\
\hline \multicolumn{4}{|c|}{ TAG-3 (South) Lower terrace, $55 \mathrm{~m}$ south of black smoker complex, $3652 \mathrm{~m}$ depth } \\
\hline $957 Q^{*}$ & $0.0-14.5$ & 40.8 & Sulfide and Si-Fe oxyhydroxide drill cuttings \\
\hline \multicolumn{4}{|c|}{ TAG-4 (West) Upper terrace, $30 \mathrm{~m}$ west of black smoker complex, $3645 \mathrm{~m}$ depth. } \\
\hline 957I & $9.0-13.5$ & 17.1 & Porous sulfide, sulfide-quartz \\
\hline 957J & $0.0-9.0$ & 0.9 & Si-Fe oxyhydroxide, massive sulfide \\
\hline $957 \mathrm{~K}$ & $0.0-20.0$ & 5.0 & Massive (porous) sulfide \\
\hline $957 \mathrm{M}$ & $0.0-51.2$ & 13.6 & $\begin{array}{l}\text { Fe-oxide drill cuttings, Si-Fe oxyhydroxide, massive sulfide, sulfide-quartz, silicified } \\
\text { basalt, argillized basalt, basalt (slightly altered) }\end{array}$ \\
\hline \multicolumn{4}{|c|}{ TAG-5 (North) Upper terrace, $35 \mathrm{~m}$ north of black smoker complex, $3645 \mathrm{~m}$ depth. } \\
\hline 9570 & $0.0-20.5$ & 6.2 & Massive (porous) sulfide, sulfide-anhydrite, sulfide-quartz \\
\hline $957 \mathrm{P}$ & $0.0-59.4$ & 7.7 & Massive sulfide, sulfide-anhydrite, sulfide-quartz, sulfide-anhydrite drill cuttings \\
\hline
\end{tabular}

Notes: $*$ drill cuttings were recovered from a single cored interval of 957Q, preventing any interpretation of stratigraphy for TAG-3. The material is similar to that from TAG-2, 30 $\mathrm{m}$ to the east.

about $10 \mathrm{~m}$ away, corroded massive anhydrite is exposed at the surface. The TAG-1 section represents the deepest and most complete profile drilled through the TAG mound (Fig. 3). Samples recovered between 0 and 125.7 mbsf include porous $\mathrm{Fe}-\mathrm{Cu}$ sulfides; pyrite breccia variously cemented by pyrite, anhydrite or quartz; anhydrite veins; and silicified, paragonitized and chloritized basalt. It should be noted that the term "breccia" has a morphologic rather than genetic meaning in the descriptive sections of this paper (see discussion for further elaboration). Holes in the TAG-2 area are situated on the lower mound platform, in the Kremlin area of white smoker hydrothermal activity. Surface hydrothermal mineralization includes bulbous blocks of porous $\mathrm{Zn}$-Fe sulfide and chimneys composed of $\mathrm{Zn}$ sulfide and silica (Tivey at al., 1995). Cores recovered from depths of 0 to $54.5 \mathrm{mbsf}$ contain $\mathrm{Si}-\mathrm{Fe}$ oxyhydroxide and breccia composed of sulfide, quartz and anhydrite, similar to those from TAG-1. Silicified basalt is present in the deepest cores (from Hole 957H). Relatively unaltered basalt was encountered at 20 mbsf in the most southeasterly hole (957B) (Fig. 3). The TAG-3 area was explored by a single shallow hole. The samples recovered are similar to those from TAG-2, which is only $30 \mathrm{~m}$ away. Because mainly drill cuttings were recovered, this site will not be considered further. The TAG-4 area is $30 \mathrm{~m}$ west of the black smoker complex, on a sulfide talus-covered plateau. The mound surface in this area has low conductive heat flow, inferred to indicate an area of seawater recharge into the mound (Becker and Von Herzen, 1996). The surface is covered by blocks of Si-Fe oxyhydroxides and massive Fe-sulfide (Tivey at al., 1995). Cores were recovered from between 0 and 51.2 mbsf and contain porous $\mathrm{Fe}-\mathrm{Zn}$ sulfide, pyrite breccia, pyrite-quartz breccia, and altered basalt. The sequence of pyrite and quartz breccias is underlain by slightly altered basalt. TAG-5 is $35 \mathrm{~m}$ north of the black smoker complex, close to the northern talus scarp of the mound. Surface mineralization is dominantly porous $(\mathrm{Zn}, \mathrm{Fe}, \mathrm{Cu})$ sulfide typical of the top of the mound. Two holes were drilled to a maximum depth of 59.4 mbsf. A sequence dominated by sulfide-anhydrite mineralization is underlain by pyrite-quartz breccia and silicified basalt.

\section{SAMPLING AND ANALYTICAL PROCEDURES}

Mineral identification and textural descriptions are made from examination of over 250 polished thin sections in reflected and transmitted light. Additional mineral identification was made using X-ray diffraction (XRD). Quantitative analysis of sulfide phases were performed using a Cameca Camebax SX50 electron microprobe at
IFREMER Centre de Brest. Operating conditions were $27 \mathrm{kV}$ with a beam current of $100 \mathrm{nA}$ and counting time of $30 \mathrm{sec}$. This gave effective minimum detection limits as follows: $\mathrm{Se}=0.03 \mathrm{wt} \% ; \mathrm{Co}=0.04$ $\mathrm{wt} \% ; \mathrm{As}=0.04 \mathrm{wt} \% ; \mathrm{Ag}=0.04 \mathrm{wt} \% ; \mathrm{Zn}=0.06 \mathrm{wt} \% ; \mathrm{Cu}=0.07$ wt $\%$. The natural and synthetic sulfide standards used are described by Fouquet et al. (1988).

Sulfur-isotope analyses were made on small (10 to $100 \mathrm{mg}$ ) sulfide and anhydrite mineral samples extracted using a dental drill. In many cases, the fine intergrowth of sulfides prevented the recovery of mineral separates composed of a single sulfide phase; microscopic observation of a polished section from the same billet as the drilled samples allowed visual estimation of the mineral proportions present. Pairs of analyses were made on different generations of sulfide within the same sample and less than about $2 \mathrm{~cm}$ apart. Anhydrite was removed from the sulfide separates by repeated ultrasonic digestion in a sulfate-free seawater solution at room temperature. Anhydrite samples were digested in the same way, the solution filtered, and the sulfate reprecipitated as barite following the method of Hall et al. (1988). Sulfide mineral separates and barite were converted to $\mathrm{SO}_{2}$ using the method of Ueda and Krouse (1986), and the $\mathrm{SO}_{2}$ was purified by vacuum distillation. Isotopic analyses were carried out at Institut für Mineralogie, Freiberg, on a Finnigan Mat Delta E mass spectrometer. $\delta^{34} \mathrm{~S}$ is reported relative to Cañon Diablo Troilite (CDT) with an analytical uncertainty of $\pm 0.2 \%$ (2 $\sigma)$.

\section{SAMPLE DESCRIPTIONS}

Four main lithologic types are recognized from the samples recovered during Leg 158 (Table 2; Fig. 4). These are Si-Fe oxyhydroxide, massive sulfide, sulfide-anhydrite, and sulfide-quartz with altered basalt. Further subdivisions are made for distinctive subtypes such as porous sulfide or anhydrite vein mineralization. This classification is a simplification of the scheme used in the initial core descriptions (Shipboard Scientific Party, 1996). The lithologic types are described below in an order that matches a generalized vertical zonation of the TAG hydrothermal mound and underlying altered basement (Fig. 4).

\section{Si-Fe Oxyhydroxide}

Silica and Fe-oxyhydroxide precipitates recovered from within the mound include red and gray chert, gray silica, and porous $\mathrm{Fe}$-oxyhydroxide. The most abundant form is red chert composed of micro- 


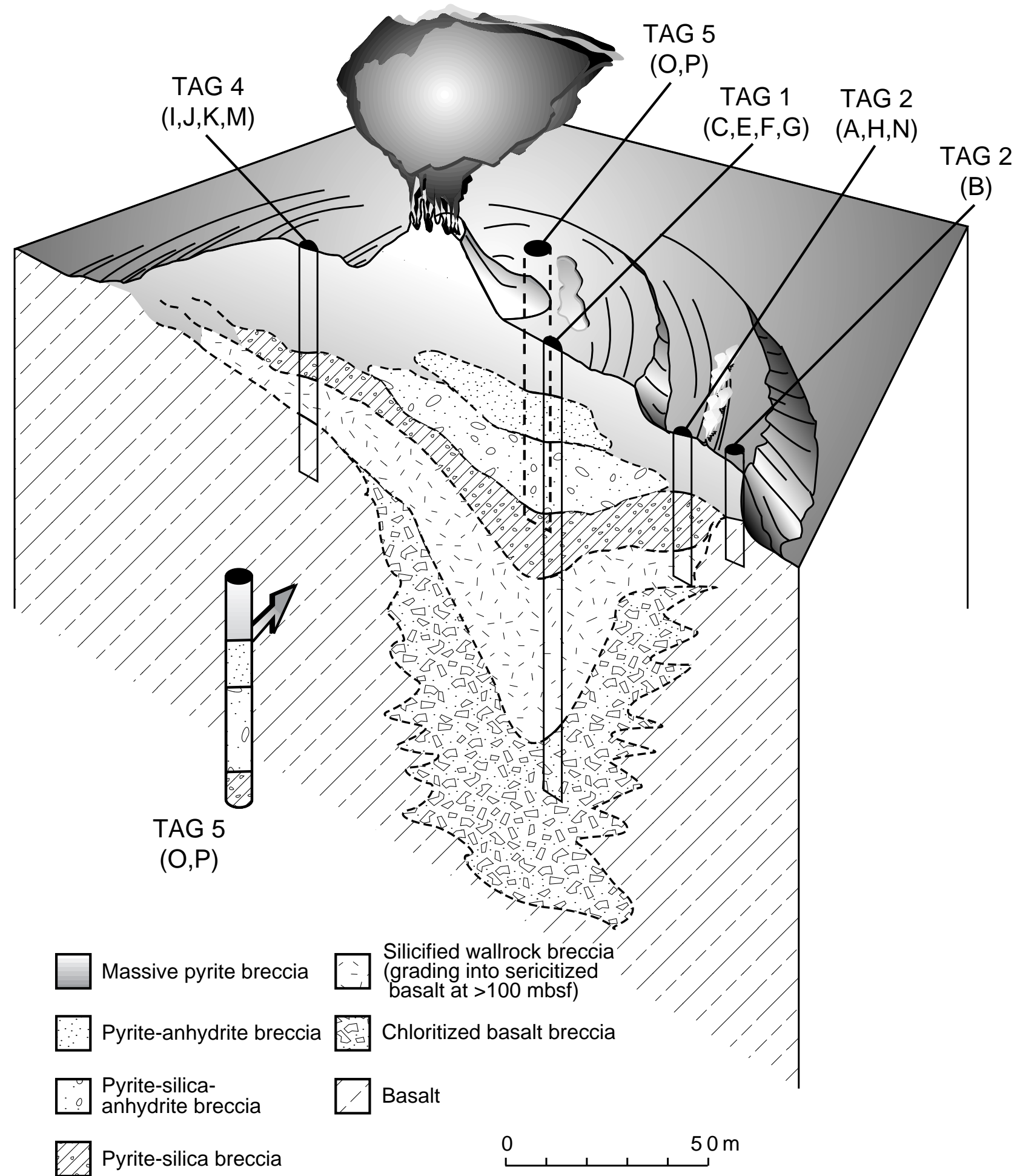

Figure 3. A schematic cross-section through the TAG hydrothermal mound showing the generalized vertical zonation and the corresponding lithology: massive sulfide zone (pyrite breccia); sulfide-anhydrite zone (pyrite-anhydrite breccia and transitional pyrite-silica-anhydrite breccia); sulfide-quartz zone (pyrite-silica breccia and silicified wallrock breccia); and altered basalt stockwork (sericitized and choloritized basalt). Letters in parentheses indicate the holes drilled at each TAG area. From Humphris et al. (1995). 
Table 2. Petrographic features in the main sample types.

\begin{tabular}{|c|c|c|c|c|}
\hline Zone: & Si-Fe oxyhydroxide & Massive sulfide & & \\
\hline Lithology: & Red and gray chert & Porous Fe-(Zn) sulfide & Porous $\mathrm{Fe}-\mathrm{Cu}$ sulfide & Pyrite breccia \\
\hline Description & $\begin{array}{l}\text { Microcrystalline quartz, disseminated } \\
\text { Fe oxyhydroxide, and minor } \\
\text { sulfide. }\end{array}$ & $\begin{array}{l}\text { Porous aggregates of fine-grained pyrite, } \\
\text { with minor to trace marcasite, } \\
\text { sphalerite, and silica. }\end{array}$ & $\begin{array}{l}\text { Porous aggregates of fine-grained } \\
\text { pyrite with local coarse granular } \\
\text { chalcopyrite aggregates. }\end{array}$ & $\begin{array}{l}\text { Compact, granular clasts of pyrite } \\
\text { cemented by finer grained sulfide. }\end{array}$ \\
\hline Occurrence & $\begin{array}{l}\text { Near-surface mineralization; clasts in } \\
\text { pyrite, pyrite-anhydrite, and pyrite- } \\
\text { quartz breccia; interpillow in } \\
\text { slightly altered basalt sequence. }\end{array}$ & $\begin{array}{l}\text { Near-surface mineralization at TAG- } 2 \\
\text { and TAG- } 4 \text {; clasts in near-surface } \\
\text { pyrite breccia; and crusts lining vugs in } \\
\text { TAG- } 4 \text {. }\end{array}$ & $\begin{array}{l}\text { Near-surface mineralization at TAG-1 } \\
\text { and TAG- } 2 \text { areas; clasts in near- } \\
\text { surface sulfide-anhydrite breccia. }\end{array}$ & $\begin{array}{l}\text { Uppermost sequence of breccia in } \\
\text { mound; downward transition to } \\
\text { pyrite-anhydrite breccia; abundant } \\
\text { in TAG-4, associated pyrite-quartz } \\
\text { breccia. }\end{array}$ \\
\hline \multicolumn{5}{|l|}{ Mineralogy } \\
\hline Pyrite & $\begin{array}{l}1 \% \text { to } 30 \% \text {. Disseminated euhedral } \\
\text { grains, commonly corroded and } \\
\text { replaced by silica; rare in situ } \\
\text { alteration to FeOx; local } \\
\text { polycrystalline aggregates. }<5-300 \\
\mu \mathrm{m} .\end{array}$ & $\begin{array}{l}20 \% \text { to } 85 \% \text {. Abundant colloform or } \\
\text { hollow spheroidal aggregates; } \\
\text { polycrystalline, banded; bladed } \\
\text { pseudomorph after marcasite; local } \\
\text { zoned euhedral grains to } 1 \mathrm{~mm} \text { in cores } \\
\text { of banded Py-Ma-Sp. }<20-400 \mu \mathrm{m} \text {. }\end{array}$ & $\begin{array}{l}0 \% \text { to } 70 \% \text {. Colloform and spheroidal } \\
\text { aggregates; local biogenic tube } \\
\text { structures } 300-\mu \mathrm{m} \text { diameter; } \\
\text { polycrystalline; euhedral grains } \\
\text { associated with Cpy. }<30-500 \mu \mathrm{m} \text {. }\end{array}$ & $\begin{array}{l}70 \% \text { to } 100 \% \text {. In clasts: in situ } \\
\text { alteration to FeOx; local } \\
\text { polycrystalline to euhedral } \\
\text { aggregates; locally microporous } \\
\text { cores with trace colloform texture; } \\
<5 \mu \mathrm{m} \text { disseminated in late silica in } \\
\text { vugs. } 50-600 \mu \mathrm{m} \text {. In matrix: porous } \\
\text { aggregates. }<50-200 \mu \mathrm{m} \text {. }\end{array}$ \\
\hline Quartz & $\begin{array}{l}50 \% \text { to } 95 \% \text {. Microcrystalline } \\
\text { aggregates with cryptocrystalline } \\
\text { or banded patches preserving traces } \\
\text { of filamentous or banded } \\
\text { amorphous precursor; coarser Qtz } \\
\text { around disseminated Py, or lining } \\
\text { vugs and fractures. }<20-200 \mu \mathrm{m}\end{array}$ & $\begin{array}{l}0 \% \text { to } 15 \% \text {. Inclusions in cores of Py; } \\
\text { chalcedony, or banded microcrystalline } \\
\text { aggregates form } 30-\mu \mathrm{m} \text { layer lining } \\
\text { vugs or fractures; disseminated } \\
\text { inclusions of corroded Py or Sp. }<10- \\
100 \mu \mathrm{m} \text {. }\end{array}$ & $\begin{array}{l}\text { Trace. Globular } 50-\mu \mathrm{m} \text { aggregates of } \\
\text { chalcedony developed on sulfide } \\
\text { grains in pore space. }\end{array}$ & $\begin{array}{l}\text { Trace to } 25 \% \text {. In clasts: Subhedral } \\
\text { inclusions in Py, or irregular } \\
\text { intergrowth in the cores of Py } \\
\text { aggregates; cryptocrystalline } \\
\text { aggregates in vugs, associated with } \\
\text { clay. }<50-200 \mu \mathrm{m} \text {. }\end{array}$ \\
\hline Anhydrite & Rare. $500-\mu \mathrm{m}$ grains in fractures & Not observed. & Not observed. & $\begin{array}{l}0 \% \text { to } 10 \% \text {. In matrix: Tabular grains } \\
\text { between Py aggregates. } 100-200 \mu \mathrm{m}\end{array}$ \\
\hline Chalcopyrite & $\begin{array}{l}\text { Trace to } 3 \% \text {. Anhedral grains } \\
\text { disseminated in FeOx-poor zones } \\
\text { of Qtz; late in vugs; commonly } \\
\text { altered to Bo-Dig-Cov. <50-100 } \\
\mu \mathrm{m} .\end{array}$ & $\begin{array}{l}\text { Trace to } 12 \% \text {. Locally intergrown with } \\
\text { Py or Sp grains; partial to complete } \\
\text { alteration to Bo-Dig-Cov. } 20-200 \mu \mathrm{m} \text {. }\end{array}$ & $\begin{array}{l}15 \% \text { to } 100 \% \text {. Anhedral intergrowth or } \\
\text { replacement of Py-Ma; inclusions in } \\
\text { Sp; late euhedral bladed in vugs } \\
\text { (max. } 2 \mathrm{~mm}) .50-500 \mu \mathrm{m} \text {. }\end{array}$ & $\begin{array}{l}\text { Trace to } 20 \% \text {. Inclusions in euhedral } \\
\text { pyrite; intergrowth with } \\
\text { polycrystalline pyrite aggregates; } \\
\text { overgrowth on Py clasts. }<20-200 \\
\mu \mathrm{m} \text {. }\end{array}$ \\
\hline Sphalerite & $\begin{array}{l}\text { Trace to } 2 \% \text {. Anhedral grains } \\
\text { disseminated in FeOx-poor zones } \\
\text { of Qtz; late in vugs or fractures. } \\
<50-100 \mu \mathrm{m} \text {. }\end{array}$ & $\begin{array}{l}\text { Trace to } 18 \% \text {. Subhedral grains } \\
\text { intergrown with pyrite-marcasite } \\
\text { (orange, zoned in TL); intergrown with } \\
\text { Cpy (opaque, Cpy disease); coarse } \\
\text { overgrowth in vugs or fractures } \\
\text { (yellow or colorless in TL). 10-400 } \\
\mu \mathrm{m} \text {. }\end{array}$ & $\begin{array}{l}\text { Trace to } 5 \% \text {. Intergrowth or late } \\
\text { overgrowth on Cpy. } 10-100 \mu \mathrm{m} \text {. }\end{array}$ & $\begin{array}{l}\text { Trace to } 5 \% \text {. Inclusions in pyrite, } \\
\text { often in clusters or aligned on } \\
\text { growth zones of host crystal; rare } \\
\text { intergrowth in Cpy. }<10-50 \mu \mathrm{m} \text {. }\end{array}$ \\
\hline Marcasite & $\begin{array}{l}\text { Trace to } 2 \% \text {. Late crusts in vugs } \\
\text { associated with Py and Sp. 50-100 } \\
\mu \mathrm{m} .\end{array}$ & $\begin{array}{l}\text { Trace to } 55 \% \text {. Polycrystalline, banded } \\
\text { aggregates intergrown with Py; } \\
\text { euhedral grains to } 600 \mu \mathrm{m} \text { in vugs. } 50- \\
200 \mu \mathrm{m} \text {. }\end{array}$ & $\begin{array}{l}\text { Trace to } 1 \% \text {. Inclusions or intergrowth } \\
\text { with Py; late, in vugs. } 20-100 \mu \mathrm{m} \text {. }\end{array}$ & $\begin{array}{l}0 \% \text { to } 30 \% \text {. Late overgrowth on Py } \\
\text { clasts, TAG- } 4.50-150 \mu \mathrm{m} \text {. }\end{array}$ \\
\hline Pyrrhotite & Not observed. & $\begin{array}{l}\text { Rare boxwork pseudomorphed by } \\
\text { microporous Py. }\end{array}$ & Not observed. & $\begin{array}{l}\text { Rare, pseudomorphed by Py. Bladed } \\
\text { crystals } 300 \mu \mathrm{m} \text {, TAG-5 only } \\
\text { (Sample } 158-957 \text { P-8R-1, 29-39 cm). }\end{array}$ \\
\hline Hematite & $\begin{array}{l}0 \% \text { to } 5 \% \text {. Submicroscopic grains } \\
\text { disseminated in quartz, locally } \\
\text { visible as bladed grains; inclusions } \\
\text { in pyrite. }<<5-30 \mu \mathrm{m} \text {. }\end{array}$ & Not observed. & Not observed. & Not observed. \\
\hline $\begin{array}{l}\text { Iron } \\
\text { oxyhydroxide }\end{array}$ & $\begin{array}{l}1 \% \text { to } \approx 30 \% \text {. Orange to dark red } \\
\text { globular or filamentous patches in } \\
\text { quartz. Globules or filaments } 5-10 \\
\mu \mathrm{m} \text { in diameter. }\end{array}$ & $\begin{array}{l}\text { Trace to } 1 \% \text {. Amorphous patches or } \\
\text { crusts around outside of pieces; less } \\
\text { commonly replaces Py on colloform } \\
\text { growth layers or in fractures. }\end{array}$ & Trace. & Not observed. \\
\hline $\begin{array}{l}\text { Amorphous } \\
\text { silica }\end{array}$ & $\begin{array}{l}0 \% \text { to } 5 \% \text {. Late, in vugs. Abundant } \\
(>90 \%) \text { in samples of porous gray } \\
\text { silica, associated with minor } \\
\text { cryptocrystalline quartz. }\end{array}$ & $\begin{array}{l}0 \% \text { to } 55 \% \text {. Globular precipitate forms } \\
20-40-\mu \mathrm{m} \text { lining of vugs or fractures in } \\
\text { some samples; local disseminated Py } \\
\text { or Sp. }\end{array}$ & $\begin{array}{l}0 \% \text { to } 10 \% \text {. Globular precipitate in } \\
\text { pore spaces; matrix to fine-grained } \\
\text { granular Py-Cpy. }\end{array}$ & $\begin{array}{l}0 \% \text { to } 5 \% \text {. Globular material in vugs } \\
\text { between pyrite grains, associated } \\
\text { with clay. }\end{array}$ \\
\hline Clay minerals & $\begin{array}{l}0 \% \text { to } 5 \% \text {. Unidentified disseminated } \\
\text { straw-yellow phase, associated with } \\
\text { altered glass in interpillow chert } \\
\text { (Sample } 158-957 \mathrm{~B}-4 \mathrm{R}-1,44-47 \mathrm{~cm} \text { ). }\end{array}$ & $\begin{array}{l}\text { Trace. Brown fibrous phyllosilicate } \\
\text { occupies intergranular porosity in Py. }\end{array}$ & $\begin{array}{l}\text { Trace. Brown fibrous phyllosilicate } \\
\text { occupies intergranular porosity in } \\
\text { Cpy-rich areas. }\end{array}$ & $\begin{array}{l}\text { Trace to 5\%. In clasts: Brown fibrous } \\
\text { phyllosilicate in vugs between } \\
\text { pyrite grains, often associated with } \\
\text { cryptocrystalline Qtz or AmSi. }\end{array}$ \\
\hline Chlorite & Not observed. & Not observed. & Not observed. & $\begin{array}{l}\text { Rare. Radiating } 50-\mu \mathrm{m} \text { aggregates in } \\
\text { vug in Py. }\end{array}$ \\
\hline Other phases & $\begin{array}{l}\text { Bornite. Trace. Alteration rim on } \\
\text { Cpy. Digenite. Trace. Grains with } \\
\text { Bo lamellae or inclusions. }<50 \mu \mathrm{m} \text {. } \\
\text { Covellite. Trace. Disseminated in } \\
\text { Cpy, Dig, or Sp. }\end{array}$ & $\begin{array}{l}\text { Bornite. Trace. Alteration of Cpy. Idaite. } \\
\text { Rare. Alteration of Cpy. Digenite. } \\
\text { Trace. Associated with Bo and Cov. } \\
\text { Covellite. Trace. Disseminated in Cpy, } \\
\text { assoc. Bo-Dig; disseminated in Sp. } \\
<10-50 \mu \mathrm{m} \text {. }\end{array}$ & $\begin{array}{l}\text { Native Au. Rare. } 7-\mu \mathrm{m} \text { grains in Cpy } \\
\text { from a single sample (Sample 158- } \\
957 \mathrm{H}-1 \mathrm{~N}-1,10-13 \mathrm{~cm}) .\end{array}$ & Not observed. \\
\hline Porosity & $\begin{array}{l}\text { Low, } 2 \% \text { to } 10 \% \text {. Higher in vuggy } \\
\text { regions or fractured pieces. }\end{array}$ & $\begin{array}{l}\text { Moderate to high, } 10 \% \text { to } 20 \% \text {. Vuggy in } \\
\text { areas of colloform Py. Reduced by } \\
\text { banded sulfide overgrowths, and late } \\
\text { void filling Ma-Sp-AmSi. }\end{array}$ & $\begin{array}{l}\text { Moderate to high, } 10 \% \text { to } 30 \% \text {. Vuggy } \\
\text { in areas of colloform Py. Lower, } \\
\text { intergranular in Cpy-rich areas. }\end{array}$ & $\begin{array}{l}\text { Moderate to low, } 5 \% \text { to } 20 \% \text {. Clasts } \\
\text { typically lower porosity }(<5 \%) \text { than } \\
\text { matrix sulfide. }\end{array}$ \\
\hline
\end{tabular}

Notes: Py = pyrite, $\mathrm{Ma}=$ marcasite, $\mathrm{Po}=$ pyrrhotite, $\mathrm{Sp}=$ sphalerite, $\mathrm{Cpy}=$ chalcopyrite, $\mathrm{Bo}=$ bornite, Dig = digenite, Cov = covellite, Anhy = anhydrite, AmSi = amorphous silica, $\mathrm{Qtz}=$ quartz, $\mathrm{Hm}=$ hematite, $\mathrm{FeOx}=\mathrm{Fe}$-oxyhydroxide. $\mathrm{TL}=$ transmitted light . 
Table 2 (continued).

\begin{tabular}{|c|c|c|c|c|}
\hline Zone: & Sulfide-anhydrite & & Sulfide-quartz & Sulfide-quartz / Altered basalt \\
\hline Lithology: & Pyrite-anhydrite & Anhydrite vein & Pyrite-quartz breccia & Altered basalt \\
\hline Description & $\begin{array}{l}\text { Compact granular clasts of pyrite in a } \\
\text { matrix of anhydrite with } 5 \% \text { to } \\
50 \% \text { disseminated sulfide. }\end{array}$ & $\begin{array}{l}<1 \mathrm{~mm} \text { to }>0.45 \mathrm{~m} \text { wide veins with } \\
\text { disseminated Cpy and Py. Cpy-Py } \\
\text { selvage on vein margin. Py halo in vein } \\
\text { wall. }\end{array}$ & $\begin{array}{l}\text { Pyrite, chert and altered basalt clast in } \\
\text { a matrix of quartz with disseminated } \\
\text { sulfide }\end{array}$ & $\begin{array}{l}\text { Basalt displaying pervasive alteration } \\
\text { to phyllosilicate or chlorite, and } \\
\text { variable degrees of silicification, } \\
\text { veining and mineralization by } \\
\text { pyrite. }\end{array}$ \\
\hline Occurrence & $\begin{array}{l}\text { Transitional from pyrite breccia with } \\
\text { increasing Anhy in matrix. Forms } \\
\text { sulfide-anhydrite zone in upper- } \\
\text { central mound at TAG-1, }-2 \text { and }-5 \text {. }\end{array}$ & $\begin{array}{l}\text { Most abundant in TAG-1, at the } \\
\text { transition between sulfide-anhydrite } \\
\text { and sulfide-quartz zones. }\end{array}$ & $\begin{array}{l}\text { Sulfide-quartz zone, transitional } \\
\text { downwards to quartz-paragonite } \\
\text { stockwork. }\end{array}$ & $\begin{array}{l}\text { Centimeter-sized clasts in pyrite and } \\
\text { pyrite-quartz breccia. Veined, } \\
\text { mineralized paragonitic, or chlorite } \\
\text { stockwork with variable } \\
\text { silicification. }\end{array}$ \\
\hline \multicolumn{5}{|l|}{ Mineralogy } \\
\hline Pyrite & $\begin{array}{l}25 \% \text { to } 85 \% \text {. In clasts: } \\
\text { Polycrystalline to euhedral } \\
\text { aggregates in clasts. } 50-600 \mu \mathrm{m} . \text { In } \\
\text { matrix: Finer euhedral grains, } \\
\text { irregular aggregates, and locally } \\
\text { microcrystalline patches or } \\
\text { colloform texture in matrix. } 20- \\
200 \mu \mathrm{m} .\end{array}$ & $\begin{array}{l}\text { In vein: trace to } 15 \% \text {. Euhedral grains } \\
\text { interstitial to anhydrite; aggregates in } \\
\text { bands; microcrystalline patches. }<10- \\
200 \mu \mathrm{m} \text {. In selvage/halo: } 20 \% \text { to } 90 \% \text {. } \\
\text { Euhedral assoc. Cpy in selvage; } \\
\text { polycrystalline to euhedral in halo. } 50- \\
500 \mu \mathrm{m} \text {. }\end{array}$ & $\begin{array}{l}20 \% \text { to } 80 \% \text {. In clasts: Euhedral (max. } \\
1.8 \mathrm{~mm} \text { ) and polycrystalline } \\
\text { aggregates, microporous cores, } \\
\text { locally fractured; euhedral grains, } \\
\text { corroded. } 50-600 \mu \mathrm{m} \text {. In matrix: } \\
\text { irregular polycrystalline or } \\
\text { microcrystalline aggregates } \\
\text { intergrown with quartz. }<50-200 \\
\mu \mathrm{m} \text {. }\end{array}$ & $\begin{array}{l}5 \% \text { to } 65 \% \text {. Fine-grained euhedral } 20- \\
200 \mu \mathrm{m} \text { dissemination and irregular } \\
\text { aggregates; In veins: coarser } 100- \\
300-\mu \mathrm{m} \text { aggregates form irregular } \\
0.5-1 \mathrm{~mm} \text { wide veinlets; coarse } \\
(\max 600 \mathrm{~m}) \text { in quartz-pyrite veins. }\end{array}$ \\
\hline Quartz & $\begin{array}{l}\text { Trace to } 5 \% \text {. In clasts: inclusions in } \\
\text { Py. More abundant in transitional } \\
\text { sulfide-quartz-anhydrite samples. } \\
20-50 \mu \mathrm{m} \text {. In matrix: intergrown } \\
\text { with (or replace) Anhy in } \\
\text { transitional sulfide-quartz- } \\
\text { anhydrite samples. } 20-100 \mu \mathrm{m} \text {. }\end{array}$ & $\begin{array}{l}\text { Trace to } 3 \% \text {. In halo: Inclusions in Py. } \\
\quad 50-100 \mu \mathrm{m} \text {. }\end{array}$ & $\begin{array}{l}10 \% \text { to } 70 \% \text {. In matrix: Mostly vuggy } \\
\text { polycrystalline aggregates; local } \\
\text { chalcedony, colloform banding, or } \\
\text { scattered euhedral grains }(0.6-2 \\
\text { mm); commonly dusty, with clear } \\
\text { euhedral halos around Py aggregates } \\
\text { or lining vugs. }<20-200 \mu \mathrm{m} \text {. }\end{array}$ & $\begin{array}{l}10 \% \text { to } 75 \% \text {. Generally fine } \\
\text { microcrystalline aggregates assoc. } \\
\text { clays; replace plagioclase; halos } \\
\text { around disseminated pyrite; }<50- \\
300 \mu \mathrm{m} \text {. In veins: coarse, elongate } \\
\text { crystals } 200-800 \mu \mathrm{m} \text {; in } 1-4 \mathrm{~mm} \\
\text { wide veins with vuggy or pyrite- } \\
\text { filled center. }\end{array}$ \\
\hline Anhydrite & $\begin{array}{l}20 \% \text { to } 60 \% \text {. Tabular or granular } \\
\text { aggregates in matrix; sulfide } \\
\text { inclusions in only a few samples; } \\
\text { rare in vugs within clasts. } 50 \mu \mathrm{m} \text { to } \\
1 \mathrm{~mm}(\max .4 \mathrm{~mm}) \text {. }\end{array}$ & $\begin{array}{l}80 \% \text { to } 100 \% \text { Tabular. granular, fibrous } \\
\text { radiating or boxwork aggregates; } \\
\text { sulfide inclusions rare. } 100 \mu \mathrm{m} \text { to } 2 \\
\mathrm{~mm} \text {. }\end{array}$ & $\begin{array}{l}0 \% \text { to } 30 \% \text {. Tabular grains and } \\
\text { aggregates fill vugs, or in late } 1-2 \\
\text { mm fractures, associated with trace } \\
\text { Cpy. } 100-400 \mu \mathrm{m} .\end{array}$ & $\begin{array}{l}0 \% \text { to } 10 \% \text {. Tabular grains in late } \\
\text { fractures, vugs and forming veins. } \\
100-400 \mu \mathrm{m} \text {. Cpy. } 100-400 \mu \mathrm{m} \text {. }\end{array}$ \\
\hline Chalcopyrite & $\begin{array}{l}\text { Trace to } 45 \% \text {. In clasts: Anhedral } \\
\text { intergrowth with euhedral Py in } \\
\text { cores of Cpy-rich clasts; } \\
\text { overgrowth of clasts. }<50-200 \mu \mathrm{m} \text {. } \\
\text { In matrix: rounded interstitial } \\
\text { grains. }<50-100 \mu \mathrm{m} \text {. }\end{array}$ & $\begin{array}{l}\text { In vein: trace to } 5 \% \text {. Rounded grains } \\
\text { interstitial to Anhy, form clots or } \\
\text { bands. In selvage: } 10 \% \text { to } 35 \% \text {. } \\
\text { Anhedral, assoc. euhedral Py. } 10-400 \\
\mu \mathrm{m} \text {. In halo: trace to } 10 \% \text {. intergrowth } \\
\text { with Py. }\end{array}$ & $\begin{array}{l}\text { Trace to } 20 \% \text {. In clasts: Anhedral } \\
\text { intergrowth with Py; inclusions in } \\
\text { Py. } 50-100 \mu \mathrm{m} \text {. In matrix: trace } \\
\text { ragged grains disseminated in quartz } \\
\text { (locally abundant, esp. TAG-4); late, } \\
\text { in vugs. } 10-200 \mu \mathrm{m} \text {. }\end{array}$ & $\begin{array}{l}\text { Trace to 5\%. Rare associated with } \\
\text { disseminated Py; rare veinlets; trace } \\
\text { anhedral grains associated with Qtz- } \\
\text { Py veins; late, associated with Anhy } \\
\text { veins. } 10-200 \mu \mathrm{m} \text {. }\end{array}$ \\
\hline Sphalerite & $\begin{array}{l}\text { Trace to } 1 \% \text {. Clusters of inclusion in } \\
\text { euhedral pyrite; rare intergrowth } \\
\text { with Cpy. }<10-50 \mu \mathrm{m} \text {. }\end{array}$ & $\begin{array}{l}\text { Trace. Inclusion in Anhy, commonly } \\
\text { form secondary inclusions in Py. 5-20 } \\
\mu \mathrm{m} \text {. }\end{array}$ & $\begin{array}{l}\text { Trace to 5\%. Inclusions in pyrite. 5-20 } \\
\mu \mathrm{m} \text {. Late overgrowth on Qtz } \\
\text { aggregates, TAG-4 only. }\end{array}$ & Trace. Inclusions in pyrite. $<40 \mu \mathrm{m}$. \\
\hline Marcasite & Not observed. & Not observed. & $\begin{array}{l}0 \% \text { to } 15 \% \text {. Late overgrowth on Qtz } \\
\text { aggregates, TAG- } 4 \text { only. }\end{array}$ & Not observed. \\
\hline Pyrrhotite & $\begin{array}{l}\text { Rare. } 100-\mu \mathrm{m} \text { tabular pseudomorph } \\
\text { preserved by microporous Py; } \\
\text { TAG-5 only. }\end{array}$ & Not observed. & $\begin{array}{l}\text { Rare. Inclusions in euhedral pyrite. } \\
<15 \mu \mathrm{m} \text {. }\end{array}$ & $\begin{array}{l}\text { Rare. Inclusions in euhedral pyrite in } \\
\text { veins. }<15 \mu \mathrm{m} \text {. }\end{array}$ \\
\hline Hematite & $\begin{array}{l}\text { Rare. }<5 \mu \mathrm{m} \text { anhedral inclusions in } \\
\text { Py. }\end{array}$ & Rare. Inclusion in Cpy. & $\begin{array}{l}\text { Trace. Anhedral to bladed inclusions } \\
\text { in euhedral Py. } 10-20 \mu \mathrm{m} \text {. }\end{array}$ & Rare. Inclusions in pyrite, to $60 \mu \mathrm{m}$. \\
\hline $\begin{array}{l}\text { Iron } \\
\text { oxyhydroxide }\end{array}$ & Not observed. & $\begin{array}{l}\text { Rare. Red-stained anhydrite in a few } \\
\text { complex banded veins (e.g., Sample } \\
\text { 158-957C-7N-2, 80-106 cm). }\end{array}$ & $\begin{array}{l}\text { Trace. Small patches of very fine- } \\
\text { grained red FeOx locally } \\
\text { disseminated in quartz }\end{array}$ & $\begin{array}{l}\text { Trace. Very fine-grained red } \mathrm{FeOx} \\
\text { locally disseminated in quartz. }\end{array}$ \\
\hline $\begin{array}{l}\text { Amorphous } \\
\text { silica }\end{array}$ & $\begin{array}{l}\text { Rare. In clasts: Late globular } \\
\text { precipitate in vugs assoc. clay. }\end{array}$ & Not observed. & Not observed. & Not observed. \\
\hline Clay minerals & $\begin{array}{l}\text { Trace. In clasts: Brown or colorless, } \\
\text { fibrous aggregates in vugs in Py } \\
\text { aggregates. }\end{array}$ & $\begin{array}{l}\text { Trace. Brown, fibrous in vugs in Py } \\
\text { selvage or halo }\end{array}$ & $\begin{array}{l}\text { Trace to } 5 \% \text {. Brown dusty patches in } \\
\text { quartz aggregates; coarse-grained, } \\
\text { fibrous clear aggregates interstitial } \\
\text { to coarse quartz; in vugs between } \\
\text { Qtz or Py. }\end{array}$ & $\begin{array}{l}1 \% \text { to } 65 \% \text {. Very fine-grained brown } \\
\text { or coarser colorless Na-rich } \\
\text { phyllosilicate (paragonite); } \\
\text { preserves basalt microtextures; } \\
\text { irregular } 0.5-1 \text { mm veinlets; } \\
\text { disseminated in quartz. }\end{array}$ \\
\hline Chlorite & $\begin{array}{l}\text { Trace. In clasts: Fibrous } 50-\mu \mathrm{m} \\
\text { spherical aggregates in vugs n Py } \\
\text { aggregates. }\end{array}$ & $\begin{array}{l}\text { Trace to } 3 \% \text {. Spherical aggregates } \\
\text { especially close to selvage zone. }\end{array}$ & $\begin{array}{l}\text { Trace. Spherical } 50-\mu \mathrm{m} \text { aggregates } \\
\text { locally in vugs between Py or Qtz } \\
\text { grains. }\end{array}$ & $\begin{array}{l}0 \% \text { to } 50 \% \text {. Complex alteration halo } \\
\text { and vein relationship with Na-rich } \\
\text { phyllosilicate in some samples; fills } \\
\text { vesicles. }\end{array}$ \\
\hline Other phases & $\begin{array}{l}\text { Digenite. Rare inclusion in Anhy. } 15 \\
\mu \mathrm{m} \text {. Tennantite. Rare } 20 \mu \mathrm{m}- \\
\text { inclusions with Sp inclusions in Py } \\
\text { from a single sample (Sample 158- } \\
957 \mathrm{C}-13 \mathrm{~N}-1,12-20 \mathrm{~cm})\end{array}$ & Not observed. & $\begin{array}{l}\text { TiFeOx (rutile?). Rare. Inclusions in } \\
\text { pyrite or scattered in dusty quartz. } \\
<1-5 \mu \mathrm{m} \text {. }\end{array}$ & $\begin{array}{l}\text { TiFeOx. Trace. }<2 \mu \mathrm{m} \text { skeletal grains } \\
\text { in clay or quartz; anhedral rutile (?) } \\
\text { inclusions in Py. Isocubanite. Rare. } \\
5-\mu \mathrm{m} \text { inclusion with Cpy } \\
\text { intergrowth in pyrite }(158-957 \mathrm{P}- \\
12 \mathrm{R}-2,15-19 \mathrm{~cm}) .\end{array}$ \\
\hline Porosity & $\begin{array}{l}\text { Moderate to low, } 5 \% \text { to } 15 \% \text {. } \\
\text { Intergranular to anhydrite. }\end{array}$ & $\begin{array}{l}\text { Moderate, } 5 \% \text { to } 15 \% \text {. Intergranular to } \\
\text { anhydrite.Increased in zones of coarse } \\
\text { anhydrite, or by the development of } \\
\text { dissolution cavities. }\end{array}$ & $\begin{array}{l}\text { Moderate to low, } 2 \% \text { to } 15 \% \text {. Vugs } \\
\text { within quartz aggregates or cavities } \\
\text { around sulfides. Fractures. Reduced } \\
\text { by late anhydrite. }\end{array}$ & $\begin{array}{l}\text { Low, } 2 \% \text { to } 10 \% \text {. Fractures and vuggy } \\
\text { veins, reduced by clay, pyrite, or } \\
\text { quartz deposition. }\end{array}$ \\
\hline
\end{tabular}




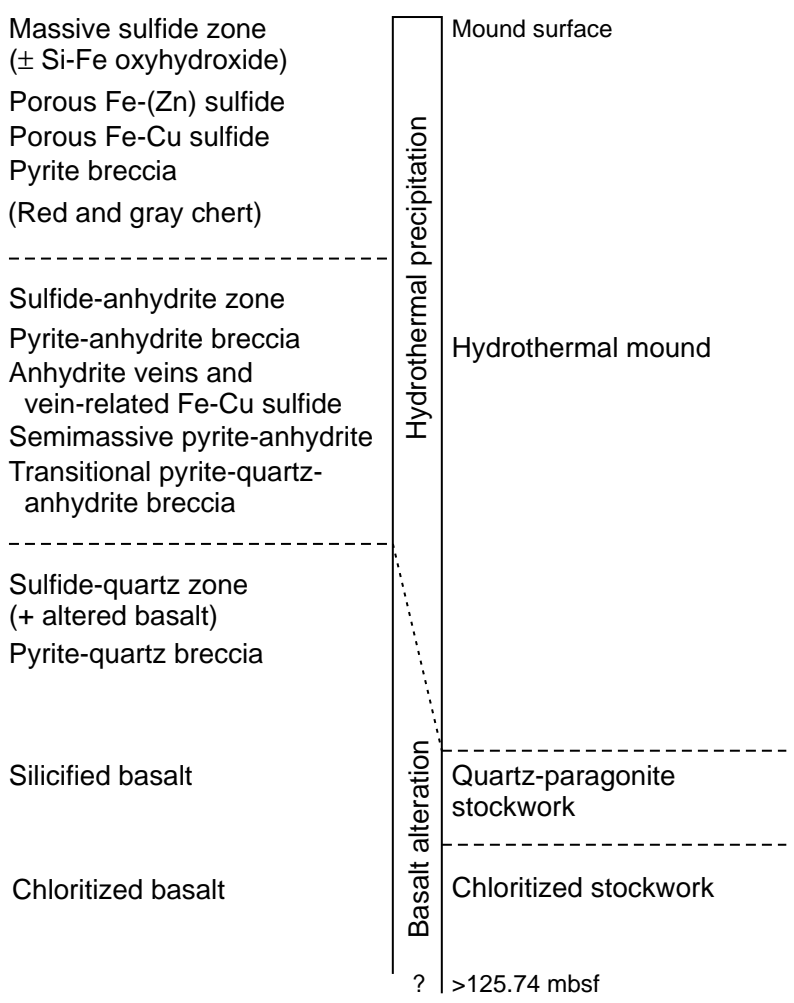

Figure 4. An idealized vertical zonation through the mound (not to scale) to summarize the different sample types found in the sulfide, sulfide-anhydrite, and sulfide-quartz zones.

crystalline quartz and disseminated Fe-oxyhydroxide (Table 2). Chert samples were mostly recovered as small $(<4 \mathrm{~cm})$ pieces, commonly associated with porous sulfide. Red chert is also present throughout the mound, where it occurs as small $(<2 \mathrm{~cm})$ patches or clasts in the various breccia types.

\section{Massive Sulfide Mineralization}

Massive sulfide is composed of $>75$ vol\% sulfide (Shipboard Scientific Party, 1996), and may be subdivided on a textural basis into porous sulfide and sulfide breccia. Porous sulfide is composed of generally fine-grained sulfide aggregates with a high (>10 vol\%) vuggy porosity. Two mineral associations are distinguished. Porous $\mathrm{Fe}-(\mathrm{Zn})$ sulfide is composed of pyrite and marcasite with variable proportions of sphalerite, silica, and trace chalcopyrite (Table 2). Porous $\mathrm{Fe}-\mathrm{Cu}$ sulfide is composed of pyrite, with locally abundant chalcopyrite.

Massive pyrite breccia is composed of compact, granular pyrite clasts in a sulfide matrix. Macroscopically, clasts are distinguished by their subrounded or angular morphology and range in size from a few millimeters to $>5 \mathrm{~cm}$ in diameter. Like the term "breccia," the word "clast" is used here in a purely morphologic sense without any genetic implications (see discussion). The matrix sulfide is typically composed of fine- to medium-grained pyrite aggregates with trace to minor chalcopyrite and anhydrite.

\section{Sulfide-Anhydrite Mineralization}

Sulfide-anhydrite mineralization mainly occurs as breccia and in veins. Pyrite-anhydrite breccia is composed of compact granular pyrite clasts cemented by a matrix of anhydrite with variable propor- tions (5-50 vol\%) of fine-grained $(<1 \mathrm{~mm})$ disseminated pyrite and chalcopyrite (Table 2). Clasts are similar in size and morphology to those in the pyrite breccia.

Anhydrite veins occur in pyrite-anhydrite breccia, pyrite-quartz breccia, and silicified basalt. The veins form distinct planar-walled structures and more irregular patches in fractures, vugs and cavities. Vein width ranges from $<1 \mathrm{~mm}$ to $>0.4 \mathrm{~m}$. Cu-Fe sulfide mineralization associated with anhydrite veining occurs both within the vein and along the vein margins. Within the vein, sulfide mineralization is usually a volumetrically minor component ( $<<15$ vol\%): chalcopyrite and pyrite occur in some of the thicker veins as localized bands or clots; disseminated sulfide is rare except in gray, banded veins. The most abundant $\mathrm{Fe}-\mathrm{Cu}$ sulfide mineralization is concentrated at the vein margins, forming pyrite-chalcopyrite selvages and massive pyrite halos. Pyrite-chalcopyrite selvages range in thickness from 1 to $10 \mathrm{~mm}$. Haloes of compact granular pyrite 2 to $50 \mathrm{~mm}$ in thickness are commonly developed in the vein wall. These are fractured or brecciated, with the fractures infiltrated by anhydrite.

\section{Sulfide-Quartz Mineralization and Altered Basalt}

Sulfide-quartz mineralization is dominantly composed of pyritequartz breccia containing isolated clasts or patches of silicified basalt. Pyrite-quartz breccia has a simple pyrite- and quartz-dominated mineralogy, but displays considerable heterogeneity in texture. This heterogeneity is mainly because of the variable grain size and morphology of the pyrite and quartz aggregates (Table 2), but also to the presence of altered basalt, fracturing, anhydrite veining, and veinrelated $\mathrm{Fe}-(\mathrm{Cu})$ sulfide mineralization. Breccia textures vary from simple nodular $(0.2$ to $1.5 \mathrm{~cm})$ clasts in vuggy quartz, to complex semi-massive intergrowth of quartz and pyrite aggregates.

Altered basalt takes the form of a paragonitic or chloritic matrix with fine-grained, disseminated pyrite \pm quartz (Honnorez et al., Chap. 18, this volume). Centimeter-sized silicified clasts with recognizable basalt microtextures occur through most of the mound sequence, preserved in pyrite or pyrite-quartz breccia. In the mineralized quartz-paragonite stockwork, the altered basalt shows variable degree of silicification and is cut by quartz and pyrite veins up to 2 $\mathrm{cm}$ wide. The quartz-paragonite is transitional to dominantly chlorite alteration in the deepest part of the stockwork. Petrographic descriptions of the altered basalt are presented by Honnorez et al. (Chap. 18, this volume).

\section{PETROLOGY AND SULFIDE GEOCHEMISTRY OF HYDROTHERMAL MINERALIZATION}

The TAG mound has a relatively simple mineralogy (Table 2), with greater than $90 \mathrm{vol} \%$ accounted for by the major phases pyrite, quartz, anhydrite, and chalcopyrite. Aluminosilicate phases (Na-rich phyllosilicate, chlorite) are locally abundant in the altered basalt (Honnorez et al., Chap. 18, this volume). Other minor phases with localized distribution include sphalerite, marcasite, amorphous silica, and Fe-oxyhydroxide. Despite the simple mineralogy, there is considerable heterogeneity in the textures and distribution of phases, both at the scale of mound zonation (tens of meters) and within individual centimeter-sized samples.

Pyrite is the most abundant and ubiquitous mineral in the TAG mound. Fine-grained $(<10 \mu \mathrm{m})$, colloform, and spheroidal pyrite is abundant in sulfides from the upper $20 \mathrm{~m}$ of the mound. These textures commonly form a porous foundation in $\mathrm{Fe}-(\mathrm{Zn})$ and $\mathrm{Fe}-\mathrm{Cu}$ sulfides. The foundation is overgrown by coarse-grained pyrite, by marcasite-sphalerite-silica or by chalcopyrite (PI. 1, Fig. 1). Coarse euhedral pyrite is mainly developed in near-surface samples associated with chalcopyrite. Below 20 mbsf, pyrite typically occurs as coarsegrained $(>100 \mu \mathrm{m})$ euhedral crystals or polycrystalline aggregates. However, a distinctive microcrystalline pyrite texture (Pl. 1, Fig. 2) 
was observed in samples of pyrite-anhydrite breccia, anhydrite veins, and rarely in pyrite-quartz breccia. The poor crystallinity and partial transition to coarser polycrystalline aggregates suggest that the microcrystalline pyrite is a primary in situ precipitate and is a possible precursor to coarse-grained pyrite aggregates.

Massive pyrite clasts in pyrite, pyrite-anhydrite, and pyrite-quartz breccias, and the massive pyrite haloes of anhydrite veins are microtexturally identical. They are composed of compact granular aggregates of polycrystalline and euhedral pyrite. Localized regions of microporous, finer grained (50 to $100 \mu \mathrm{m}$ ) pyrite (Pl. 1, Fig. 3) preserve the ghosts of colloform and spheroidal textures. This suggests that the granular pyrite may have originated by recrystallization of porous sulfides. However, pyrite halos and nodular clasts in pyrite-anhydrite breccia commonly display sequential banded generations of coarse pyrite (Pl. 1, Fig. 4). Compositional zonation (variable Co content, see below) mirrors the layers, indicating that this coarse pyrite precipitated directly as sequential overgrowth rather than by recrystallization.

Different pyrite generations from porous sulfides, breccias, and altered basalt were analyzed for trace elements by electron microprobe. A small number of pyrite grains contain up to $0.42 \mathrm{wt} \% \mathrm{Cu}$ and $0.65 \mathrm{wt} \% \mathrm{Zn}$ (Table 3); these elevated values may be a result of the presence of chalcopyrite or sphalerite inclusions below the surface of the polished section. Chalcopyrite-bearing porous and veinrelated sulfide samples contained proportionally more pyrite grains with detectable $\mathrm{Cu}$.

Of the trace elements analyzed, only Co was above detection limits (Table 3). Cobalt concentration in pyrite ranges from $<0.04$ to 1.96 $\mathrm{wt} \%$ (median $0.160 \mathrm{wt} \%$ ) and is above detection limits in 52 of the 128 analyses. The highest Co concentrations are in pyrite disseminated in silicified basalt and in pyrite aggregates from pyrite-anhydrite breccia (Table 3). Generations of euhedral pyrite associated with chalcopyrite in porous and vein-related $\mathrm{Fe}-\mathrm{Cu}$ sulfide also contain high Co (up to $0.795 \mathrm{wt} \%$ ). In contrast, pyrite-quartz breccia and porous $\mathrm{Fe}$-(Zn) sulfide samples contain pyrite with low Co-contents.

There is a heterogeneous distribution of Co within individual pyrite grains. Euhedral pyrite disseminated in silicified basalt commonly displays oscillatory growth zonation. Up to $1.96 \mathrm{wt} \%$ Co is present in narrow 5- $\mu \mathrm{m}$ zones. Generations of euhedral pyrite overgrowths on nodular clasts in the sulfide-anhydrite breccia (e.g., Pl. 1, Fig. 4) also display Co-rich zones which follow the outline of the clast. Pyrite in the porous cores of these clasts does not contain detectable Co.

Chalcopyrite is the second most abundant sulfide (after pyrite). It occurs as a trace to minor component in all lithologic types, although it is concentrated in near-surface porous sulfides and in the sulfide mineralization associated with anhydrite veins (Table 2). Euhedral, bladed chalcopyrite is confined to porous $\mathrm{Fe}-\mathrm{Cu}$ sulfide samples or rarely occurs as clasts in pyrite-anhydrite breccia within $15 \mathrm{~m}$ of the mound surface. This habit is similar to that in conduit linings around black smoker vents. Most commonly, chalcopyrite occurs as anhedral grains intergrown with (and locally replacing) polycrystalline or euhedral pyrite. Chalcopyrite-pyrite aggregates form clasts in pyriteanhydrite breccia and selvage mineralization along the margins of some anhydrite veins. In chalcopyrite-poor samples, chalcopyrite is confined to small inclusions in pyrite or is disseminated in the breccia matrix.

Fifty-seven microprobe analyses were made on chalcopyrite grains from 11 different samples of porous sulfide, pyrite-anhydrite breccia, pyrite-quartz breccia, and vein-related sulfide mineralization in an attempt to document deviations from stoichiometry and variations in trace element content, particularly Se. Chalcopyrite displays only small compositional variation around the stoichiometric composition (Fig. 5). All generations contain low concentrations of the elements analyzed (that is, Se $<0.03 \mathrm{wt} \%$; Co $<0.04 \mathrm{wt} \%$; As $<0.04$ wt $\%$; Ag $<0.04 \mathrm{wt} \%$; and $\mathrm{Zn}<0.07 \mathrm{wt} \%$ ).

Sphalerite is a trace mineral in most of the mound, where it is confined to small inclusions within pyrite. This association is seen in all pyrite generations except pyrite disseminated in altered basalt. The inclusions are anhedral, typically form clusters distributed on growth zones in the host crystal and are sometimes associated with chalcopyrite or hematite. Locally, sphalerite inclusions are also present in vein anhydrite.

Significant enrichment of sphalerite (up to $18 \mathrm{vol} \%$ ) is seen in porous sulfides from the upper 10-20 m of the mound (only in the TAG-2 and TAG-4 areas). Anhedral or subhedral, zoned, orange or brown-colored crystals overgrow colloform pyrite in vugs, associated with marcasite, silica, and minor chalcopyrite. Distinctive sphalerite types are observed: sphalerite associated with chalcopyrite

Table 3. Pyrite composition: variation in cobalt, copper, and zinc contents, determined by electron microprobe.

\begin{tabular}{|c|c|c|c|c|c|c|c|c|c|c|c|c|c|}
\hline \multirow[b]{2}{*}{$\begin{array}{l}\text { Core, section, } \\
\text { interval }(\mathrm{cm})\end{array}$} & \multirow[b]{2}{*}{$\begin{array}{l}\text { Depth } \\
\text { (mbsf) }\end{array}$} & \multicolumn{4}{|c|}{ Co (wt \%) } & \multicolumn{4}{|c|}{$\mathrm{Cu}(\mathrm{wt} \%)$} & \multicolumn{4}{|c|}{$\mathrm{Zn}(\mathrm{wt} \%)$} \\
\hline & & Min. & Median & Max. & $>\mathrm{MDL}$ & Min. & Median & Max. & $>$ MDL & Min. & Median & Max. & $>$ MDL \\
\hline $\begin{array}{l}\text { Porous Fe-(Zn) sulfide } \\
\text { 957K-1X-1, 35-38 } \\
\text { 957M-2R-1, 15-20 }\end{array}$ & $\begin{array}{l}0.30 \\
9.44\end{array}$ & $\begin{array}{l}<0.04 \\
<0.04\end{array}$ & - & 二 & $\begin{array}{l}0 / 4 \\
0 / 2\end{array}$ & $\begin{array}{l}<0.07 \\
<0.07\end{array}$ & - & $\stackrel{0.203}{-}$ & $\begin{array}{l}1 / 4 \\
0 / 2\end{array}$ & $\begin{array}{c}<0.06 \\
0.218\end{array}$ & $0 . \overline{236}$ & $0 . \overline{254}$ & $\begin{array}{l}0 / 4 \\
2 / 2\end{array}$ \\
\hline $\begin{array}{l}\text { Porous Fe-Cu sulfide } \\
\text { 957F-1N-1, 19-21 }\end{array}$ & 1.17 & $<0.04$ & 0.162 & 0.207 & $5 / 11$ & $<0.07$ & 0.122 & 0.235 & $7 / 11$ & $<0.06$ & - & 0.211 & $1 / 11$ \\
\hline $\begin{array}{l}\text { Pyrite-anhydrite breccia } \\
\text { 957C-7N-2, 144-149 } \\
\text { 957P-3R-1, 1-4 }\end{array}$ & $\begin{array}{l}22.12 \\
11.90\end{array}$ & $\begin{array}{l}<0.04 \\
<0.04\end{array}$ & $\begin{array}{l}0.157 \\
0.272\end{array}$ & $\begin{array}{l}0.222 \\
1.066\end{array}$ & $\begin{array}{l}4 / 13 \\
9 / 17\end{array}$ & $\begin{array}{l}<0.07 \\
<0.07\end{array}$ & $\begin{array}{c}0.323 \\
-\end{array}$ & $\begin{array}{c}0.388 \\
-\end{array}$ & $\begin{array}{l}2 / 13 \\
0 / 17\end{array}$ & $\begin{array}{l}<0.06 \\
<0.06\end{array}$ & - & - & $\begin{array}{l}0 / 13 \\
0 / 17\end{array}$ \\
\hline $\begin{array}{l}\text { Semi-massive pyrite-anhydrite } \\
957 \mathrm{P}-8 \mathrm{R}-1,29-30\end{array}$ & 35.37 & $<0.04$ & 0.084 & 0.297 & $6 / 19$ & $<0.07$ & 0.122 & 0.188 & $5 / 19$ & $<0.06$ & - & - & 0/19 \\
\hline $\begin{array}{l}\text { Vein-related Fe-Cu sulfide } \\
\text { 957C-16N-1, 52-57 } \\
\text { 957E-16R-1,1-4 }\end{array}$ & $\begin{array}{r}46.72 \\
111.10\end{array}$ & $\begin{array}{l}<0.04 \\
<0.04\end{array}$ & $0 . \overline{087}$ & $\begin{array}{l}0.065 \\
0.795\end{array}$ & $\begin{array}{l}1 / 3 \\
8 / 12\end{array}$ & $\begin{array}{l}<0.07 \\
<0.07\end{array}$ & $0 . \overline{0} 72$ & $0 . \overline{129}$ & $\begin{array}{l}0 / 3 \\
5 / 12\end{array}$ & $\begin{array}{l}<0.06 \\
<0.06\end{array}$ & - & $0 . \overline{645}$ & $\begin{array}{l}0 / 3 \\
1 / 12\end{array}$ \\
\hline $\begin{array}{c}\text { Pyrite-quartz breccia } \\
957 \mathrm{C}-16 \mathrm{~N}-1,52-57 \\
957 \mathrm{M}-2 \mathrm{R}-1,15-20\end{array}$ & $\begin{array}{r}46.72 \\
9.44\end{array}$ & $\begin{array}{l}<0.04 \\
<0.04\end{array}$ & $\begin{array}{l}0.044 \\
0.064\end{array}$ & $\begin{array}{l}0.045 \\
0.073\end{array}$ & $\begin{array}{l}2 / 3 \\
2 / 6\end{array}$ & $\begin{array}{l}<0.07 \\
<0.07\end{array}$ & $0 . \overline{243}$ & $\begin{array}{c}0.098 \\
0.421\end{array}$ & $\begin{array}{l}1 / 3 \\
2 / 6\end{array}$ & $\begin{array}{l}<0.06 \\
<0.06\end{array}$ & - & - & $\begin{array}{l}0 / 3 \\
0 / 6\end{array}$ \\
\hline $\begin{array}{l}\text { Silicified basalt } \\
\text { 957E-14R-1, 30-36 } \\
\text { 957E-16R-1, 1-4 } \\
\text { 957M-7R-1, 8-12 }\end{array}$ & $\begin{array}{r}101.80 \\
111.10 \\
34.35\end{array}$ & $\begin{array}{l}<0.04 \\
<0.04 \\
<0.04\end{array}$ & $\begin{array}{l}0.123 \\
0.804 \\
0.367\end{array}$ & $\begin{array}{l}0.261 \\
1.956 \\
0.694\end{array}$ & $\begin{array}{l}5 / 12 \\
5 / 12 \\
5 / 14\end{array}$ & $\begin{array}{l}<0.07 \\
<0.07 \\
<0.07\end{array}$ & $\bar{z}$ & $\begin{array}{l}0.270 \\
0 . \overline{093}\end{array}$ & $\begin{array}{l}1 / 12 \\
0 / 12 \\
1 / 14\end{array}$ & $\begin{array}{l}<0.06 \\
<0.06 \\
<0.06\end{array}$ & 二 & 二 & $\begin{array}{l}0 / 12 \\
0 / 12 \\
0 / 14\end{array}$ \\
\hline
\end{tabular}

Notes: >MDL is the number of analyses above the minimum detection limit, as a ratio of the total number of analyses. $-=$ not determined. The following elements were analyzed for but were below detection: Se $<0.03$ wt $\%$; As $<0.04$ wt $\%$; Ag $<0.04$ wt $\%$. 


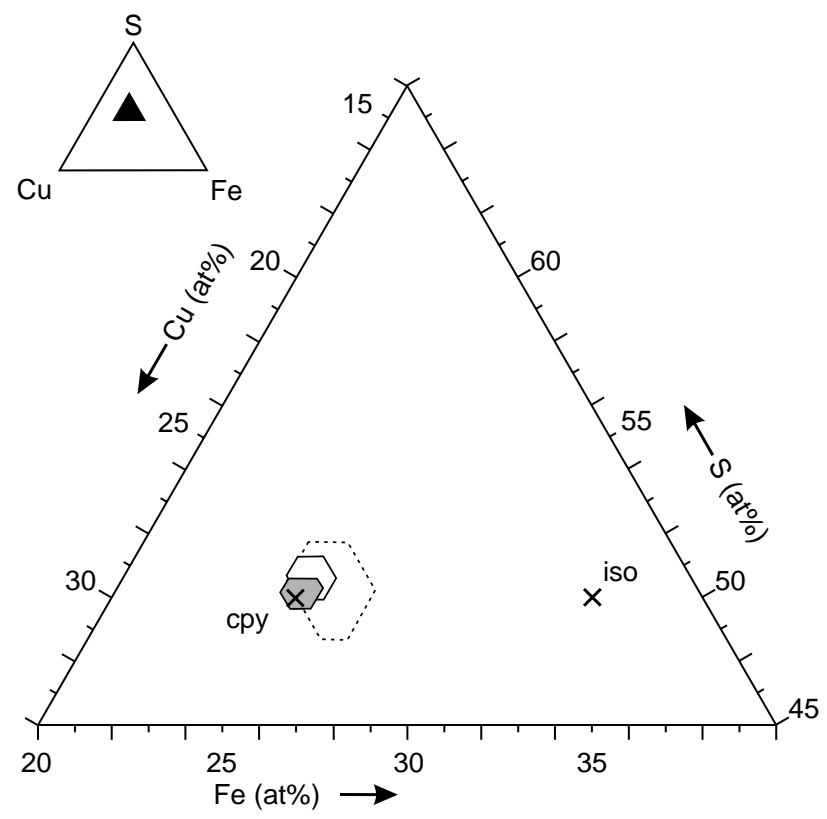

Figure 5. Cu-Fe-S ternary plot showing the limited chalcopyrite compositional variation of subsurface samples (shaded region) compared to surface TAG samples (solid line; Tivey et al., 1995) and East Pacific Rise (EPR) $21^{\circ} \mathrm{N}$ (dashed line; Lafitte and Maury, 1983). $\times$ 's mark stoichiometric chalcopyrite (cpy) and isocubanite (iso). at $\%=$ atomic percent.

is opaque and contains fine chalcopyrite "disease" inclusions (cf. Barton and Bethke, 1987); late sphalerite associated with silica in vugs is pale yellow or colorless in transmitted light.

The Fe-content of sphalerite is low (Table 4), ranging from 0.95 to $5.85 \mathrm{wt} \%$ (mean and standard deviation $2.50 \pm 1.06 \mathrm{wt} \% \mathrm{Fe}$ ). Sphalerite associated with chalcopyrite in porous $\mathrm{Fe}-\mathrm{Cu}$ sulfide has a slightly higher and more variable Fe-content (mean $3.11 \pm 1.02 \mathrm{wt} \%$ $\mathrm{Fe}$ ) than sphalerite with a pyrite-marcasite association in porous $\mathrm{Fe}$ $\mathrm{Zn}$ sulfide $(2.54 \pm 0.26 \mathrm{wt} \% \mathrm{Fe})$. Deeper in the mound, sphalerite associated with a late pyrite-marcasite crust on pyrite breccia (Sample 158-957M-2R-1, 15-20 cm) contained the lowest and least variable Fe content (mean $1.24 \pm 0.22 \mathrm{wt} \% \mathrm{Fe}$ ).

The uniformly high $\mathrm{Cu}$ in sphalerite from the $\mathrm{Fe}-\mathrm{Cu}$ sulfide sample (Table 4) is probably incorporated within the sphalerite crystal lattice, although it could be caused by the presence of chalcopyrite inclusions. Sphalerite grains containing visible chalcopyrite "disease" were avoided during analysis and the maximum $\mathrm{Cu}$ content of up to $0.77 \mathrm{wt} \%$ is well within the experimentally determined limits of $\mathrm{CuS}$ solubility in sphalerite (Kojima and Sugaki, 1985).

Marcasite is a minor phase restricted to near-surface ( $<25 \mathrm{mbsf}$ ) porous $\mathrm{Fe}-(\mathrm{Zn})$ sulfide mineralization. It occurs as polycrystalline, banded intergrowth with pyrite. Successive banded generations vary between $<5$ vol\% and greater than 95 vol\% marcasite. Euhedral, tabular marcasite crystals are commonly developed in vugs in porous $\mathrm{Fe}-(\mathrm{Zn})$ sulfide. Marcasite may be partly replaced by chalcopyrite, or locally inverted to pyrite to form tabular, microporous pseudomorphs (cf. Murowchick, 1992).

Anhydrite is present in abundant to trace proportions throughout the mound except in the TAG-4 area west of the black smoker complex. It occurs as the matrix to pyrite-anhydrite breccia, in veins, and as late precipitates in vugs and fractures to at least $125 \mathrm{~m}$ below the surface. The poor recovery of anhydrite (except in Hole 957C) may have led to an underestimation of the extent of anhydrite veining, especially in the deepest parts of the mound in the TAG-1, -2 and -5 areas. Grains are tabular, equant or anhedral, 0.1 to $1 \mathrm{~mm}$ in size. Tab-
Table 4. Sphalerite composition, determined by electron microprobe.

\begin{tabular}{|c|c|c|c|c|c|c|}
\hline & $\begin{array}{c}\mathrm{Zn} \\
(\mathrm{wt} \%)\end{array}$ & $\underset{(w t \%)}{S}$ & $\begin{array}{c}\mathrm{Fe} \\
(\mathrm{wt} \%)\end{array}$ & $\begin{array}{c}\mathrm{Cu} \\
(\mathrm{wt} \%)\end{array}$ & $\begin{array}{c}\mathrm{Ag} \\
(\mathrm{wt} \%)\end{array}$ & Total \\
\hline \multicolumn{7}{|c|}{ Porous $\mathrm{Fe}-\mathrm{Cu}$ sulfide; Sample $158-957^{\circ} \mathrm{F}-1 \mathrm{~N}-1,19-21 \mathrm{~cm} ; 1.17 \mathrm{mbsf}$} \\
\hline Core & 62.8 & 33.1 & 1.82 & 0.31 & 0.061 & 98.16 \\
\hline Rim & 61.3 & 33.0 & 2.35 & 0.39 & $<0.04$ & 96.98 \\
\hline Rim & 61.3 & 32.9 & 2.51 & 0.36 & $<0.04$ & 97.11 \\
\hline Core & 60.7 & 33.5 & 2.82 & 0.71 & $<0.04$ & 97.80 \\
\hline Core & 60.4 & 32.9 & 2.83 & 0.60 & $<0.04$ & 96.71 \\
\hline Rim & 61.9 & 33.7 & 2.88 & 0.45 & $<0.04$ & 98.86 \\
\hline Core & 60.2 & 33.0 & 2.96 & 0.77 & $<0.04$ & 96.91 \\
\hline Rim & 60.2 & 32.9 & 2.99 & 0.34 & $<0.04$ & 96.44 \\
\hline Rim & 59.0 & 33.2 & 3.74 & 0.49 & $<0.04$ & 97.35 \\
\hline $\operatorname{Rim}$ & 59.2 & 32.9 & 3.86 & 0.75 & 0.062 & 96.69 \\
\hline Rim & 57.6 & 33.2 & 5.85 & 0.54 & $<0.04$ & 97.16 \\
\hline \multicolumn{7}{|c|}{ Porous Fe-Zn sulfide; Sample 158-957K-1X, $35-38 \mathrm{~cm} ; 0.30 \mathrm{mbsf}$} \\
\hline Core & 63.1 & 33.1 & 2.24 & $<0.04$ & 98.45 & \\
\hline Core & 61.8 & 33.1 & 2.33 & 0.14 & $<0.04$ & 97.39 \\
\hline Core & 62.1 & 33.2 & 2.47 & $<0.07$ & $<0.04$ & 97.79 \\
\hline Core & 61.8 & 33.0 & 2.58 & 0.30 & $<0.04$ & 97.76 \\
\hline Core & 62.6 & 33.0 & 2.64 & 0.07 & $<0.04$ & 98.37 \\
\hline Core & 60.2 & 33.1 & 2.98 & 0.68 & $<0.04$ & 96.93 \\
\hline \multicolumn{7}{|c|}{ Pyrite breccia; Sample 158-957M-2R-1, 15-20 cm; $9.44 \mathrm{mbsf}$} \\
\hline Core & 62.2 & 32.8 & 0.95 & 0.21 & $<0.04$ & 96.20 \\
\hline Core & 62.2 & 33.2 & 0.98 & 0.12 & $<0.04$ & 96.47 \\
\hline Core & 62.8 & 33.2 & 1.32 & 0.12 & $<0.04$ & 97.41 \\
\hline Rim & 62.4 & 33.1 & 1.36 & $<0.07$ & $<0.04$ & 96.93 \\
\hline Rim & 62.7 & 33.0 & 1.36 & 0.16 & $<0.04$ & 97.23 \\
\hline Rim & 62.5 & 33.2 & 1.49 & 0.12 & $<0.04$ & 97.31 \\
\hline Rim & 62.4 & 33.1 & 1.36 & $<0.07$ & $<0.04$ & 96.93 \\
\hline
\end{tabular}

ular crystals up to $2 \mathrm{~mm}$ occur in crustiform, banded veins, and in vugs. Anhydrite in veins is somewhat coarser grained and more heterogeneous in texture than anhydrite in the breccia matrix. Locally, grains are modified by partial dissolution, but hydration of anhydrite to gypsum was rare and confined to a few near-surface samples.

Chalcopyrite and pyrite mineralization associated with anhydrite is generally confined to small grains and aggregates interstitial to the anhydrite. Disseminated sulfide mineralization is more abundant within very fine-grained granular or fibrous anhydrite patches. This results in a general inverse relationship between anhydrite grain size and sulfide abundance. Sulfide inclusions within anhydrite crystals are uncommon except in a few sulfide-rich vein or breccia samples (Pl. 2, Fig. 1).

Quartz is present throughout the mound, generally increasing in abundance with depth into the underlying stockwork. Quartz microtextures are highly variable at a microscopic scale. Cryptocrystalline quartz and fibro-radial chalcedonic aggregates (grain size $<<10 \mu \mathrm{m}$ ) are most abundant in the upper $20 \mathrm{~m}$ of the mound associated with chert and porous sulfide. This type of quartz forms banded aggregates in vugs and fractures. Spatial association with amorphous silica and textural similarities suggest that the quartz originated by hydrothermal recrystallization of precursor amorphous silica (Oehler, 1976). Patches of cryptocrystalline quartz are observed in pyrite-quartz breccia to at least $50 \mathrm{mbsf}$.

Aggregates of equant, anhedral microcrystalline $(10-50 \mu \mathrm{m})$ and polycrystalline $(50-200 \mu \mathrm{m})$ quartz are abundant in chert and pyritequartz breccia matrix. The quartz forms polygonal aggregates 0.5 to $2 \mathrm{~mm}$ in size that contain fine-grained $(<100 \mu \mathrm{m})$, disseminated pyrite. The presence of micron-scale banding (Pl. 2, Fig. 3) preserved in clear polycrystalline aggregates suggests that the quartz originated by hydrothermal recrystallization of a banded amorphous or cryptocrystalline precursor. Clear, coarse-grained quartz without banding is commonly developed around banded or dusty quartz aggregates (Pl. 2, Figs. 3, 4). Crystals are elongate and project with euhedral terminations into the cavities between aggregates. In many breccia samples, similar clear quartz halos are developed around pyrite grains and clasts. The quartz replaces the pyrite and may ultimately leave a ragged pyrite grain with its euhedral outline preserved by the clear 
quartz (Pl. 2, Fig. 4). However, in other samples a cavity remains between the quartz and pyrite, suggesting that the pyrite could have grown later than the quartz.

Patches of much coarser grained ( $400 \mu \mathrm{m}$ to $2 \mathrm{~mm}$ ) quartz are locally developed in the pyrite-quartz breccia. Individual grains are elongate, subhedral, display undulose extinction, and have irregular grain boundaries that appear to be replaced or recrystallized to microcrystalline quartz. Scattered crystals with this morphology occur throughout the pyrite-quartz breccia.

Amorphous silica is a minor component in porous $\mathrm{Fe}-(\mathrm{Zn})$ sulfide samples. It occurs as a globular precipitate which forms a 20 - to 30$\mu \mathrm{m}$ thick veneer lining vugs, or partly filling late fractures in sulfide aggregates. Rare globular amorphous silica is associated with brown phyllosilicate in vugs in some clasts of massive pyrite. Small pieces of gray silica composed of $>90 \mathrm{vol} \%$ amorphous silica were recovered from near the surface and display fine-scale colloform banding and filamentous textures.

$\mathrm{Fe}$-oxyhydroxide was recovered from near the surface in pieces of red chert and as drill cuttings. Drill cuttings were analyzed by XRD. The absence of crystalline Fe-oxide peaks in samples obviously containing red-brown oxides suggests that amorphous $\mathrm{Fe}$-oxyhydroxide is the dominant type; goethite was only positively identified in oxide cuttings from TAG-4. In red chert, Fe-oxyhydroxide occurs as amorphous, globular or filamentous aggregates disseminated in microcrystalline quartz. Fe-oxyhydroxide also replaces colloform pyrite or marcasite, and rarely pseudomorphs euhedral pyrite in chert samples. However, these alteration phenomena are not common and are restricted to chert and porous sulfides (especially those in TAG-4) at less than about $10 \mathrm{mbsf}$.

Hematite is a minor component in red chert. It forms submicroscopic to $15-\mu \mathrm{m}$ grains disseminated in microcrystalline quartz. Hematite also occurs as rare inclusions in pyrite grains, most frequently in pyrite-quartz breccia.

Na-rich phyllosilicate is the dominant alteration product of basalt in the silicified stockwork zone beneath the mound (Honnorez et al., Chap. 18, this volume). Microprobe analyses by Honnorez et al. (Chap. 18, this volume) show that the phyllosilicate has a paragonitic composition. In addition to the direct association with altered basalt, this brown fibrous phyllosilicate also occurs throughout the mound as a trace component of all sample types. Trace phyllosilicate is commonly present in vugs within compact, granular pyrite aggregates, and also in porous $\mathrm{Fe}-\mathrm{Cu}$ sulfide and vein selvages. These occurrences are unrelated to altered basalt and are interpreted to be direct precipitates from hydrothermal fluids.

Chlorite is abundant in the chloritized stockwork and as alteration halos in basalt basement (Honnorez et al., Chap. 18, this volume). Chlorite also occurs in the central anhydrite-veined part of the mound, between about 20 and 60 mbsf, where it forms spherical 30$\mu \mathrm{m}$ fibrous aggregates and is especially concentrated in the $\mathrm{Fe}-\mathrm{Cu}$ sulfide selvage bordering anhydrite veins. Like the brown phyllosilicate, this chlorite is not spatially associated with altered basalt and is therefore interpreted to be a precipitate from hydrothermal fluids.

Of the trace minerals, pyrrhotite, secondary $\mathrm{Cu}$-sulfides, native $A u$, primary grains of pyrrhotite are rare in the TAG sulfides. Small inclusions occur in the cores of pyrite crystals from pyrite-quartz breccia and altered basalt deep in the sulfide-quartz zone. Euhedral grains of pyrrhotite were only seen in a sample of pyrite breccia from TAG-5 (Sample 158-957P-8R-1, 29-30 cm). In this sample, pyrrhotite is a late mineral, associated with chalcopyrite in vugs within a porous pyrite foundation. Elsewhere in TAG-5, pyrrhotite is altered to bladed boxwork pseudomorphs of microporous pyrite (cf. Murowchick, 1992). The euhedral pyrrhotite grains contain an average $46.35 \pm 0.14$ at $\% \mathrm{Fe}$. This composition is within the range for the monoclinic form (Kissin and Scott, 1982). Trace elements are all below detection (Co $<0.04 \mathrm{wt} \%$; $\mathrm{Se}<0.03 \mathrm{wt} \%)$, except $\mathrm{Cu}$ which ranges from 0.10 to $0.13 \mathrm{wt} \%$.
Bornite, digenite, and covellite are locally associated with chalcopyrite in near-surface samples (especially in the TAG-4 area). Chalcopyrite in these samples is partly to completely altered and replaced by fine-grained covellite, by bornite, or by digenite with lamellae or inclusions of bornite. Semiquantitative microprobe analyses indicate the presence of approximately $0.2 \mathrm{wt} \% \mathrm{Ag}$ in covellite aggregates. Covellite also occurs as very fine-grained inclusions in sphalerite. Other trace minerals identified in isolated occurrence are isocubanite, idaite, and tennantite (Table 2).

Native gold inclusions were found in chalcopyrite from a single sample of porous, granular $\mathrm{Fe}-\mathrm{Cu}$ sulfide (Table 2). Semiquantitative microprobe analyses indicate a low silver content, of the order 0.5 to $1 \mathrm{wt} \%$. The presence of visible gold in a porous sulfide has not previously been reported from the active mound. Hannington et al. (1988) documented high gold grades and visible gold grains in supergene $\mathrm{Cu}-\mathrm{Fe}$ sulfides from the mound surface. Rona et al. (1993a) and Hannington et al. (1995) describe visible gold grains associated with recrystallized chalcopyrite and with late pyrite and sphalerite veins in massive sulfides from the relict Mir zone.

Small anhedral crystals of Ti-Fe oxide (rutile?) are rarely preserved as inclusions in pyrite, in places forming distinctive parallel inclusions trails.

\section{VERTICAL DISTRIBUTION OF HYDROTHERMAL MINERALIZATION}

A generalized stratigraphy for each of the 4 main areas of the mound is shown in Figures 6 and 7. Distribution of the different types of mineralization, occurrence of minor and trace minerals, and the distribution of some distinctive textural features are also graphically summarized for each section. Estimates of depth intervals and thickness of the different lithologic types are presented in Table 5.

Holes in the TAG-1 area form the deepest and most complete reference section through the mound. Massive sulfides are present in the uppermost $12 \mathrm{~m}$ of the mound. Porous $\mathrm{Fe}-\mathrm{Cu}$ sulfide is the dominant near-surface mineralization. Pyrite breccias contain clasts with remnant colloform textures that probably formed by recrystallization of porous sulfide; colloform textures in pyrite clasts are present down to about $25 \mathrm{mbsf}$, and traces continue to at least $70 \mathrm{mbsf}$ (Fig. 6). There is a downward transition from pyrite breccia to pyrite-anhydrite breccia. This is seen as a gradual increase in the proportion of anhydrite in the matrix. The upper limit of the sulfide-anhydrite zone is located at approximately $12 \mathrm{mbsf}$, although a few pieces of anhydritecemented breccia were recovered from less than $5 \mathrm{mbsf}$ and massive anhydrite is exposed at the surface around the nearby black smoker complex (Tivey et al., 1995). With increasing depth in the sulfideanhydrite zone, the proportion of anhydrite in the matrix increases and the breccia is matrix supported. The first anhydrite veining is observed at 19.9 mbsf; the number of veins, their thickness, and their complexity increases through the lower sulfide anhydrite zone and into the sulfide-quartz zone. Anhydrite veins in the sulfide-anhydrite zone appear macroscopically continuous with matrix anhydrite. $\mathrm{Fe}$ $\mathrm{Cu}$ sulfide mineralization tends to form a poorly-defined zone along the vein margins, encrusting sulfide clasts. In contrast, anhydrite veins in the sulfide-quartz zone always occur in fractures that cut the quartz matrix and postdate quartz deposition. These veins commonly have well-defined selvages and halos of $\mathrm{Fe}-\mathrm{Cu}$ sulfide.

The change from sulfide-anhydrite zone to sulfide-quartz zone is marked by a transition zone at least $7 \mathrm{~m}$ thick. Pyrite-quartz-anhydrite breccia in this zone contains both pyrite and pyrite-quartz clasts, and quartz also replaces anhydrite in the matrix. The top of the pyritequartz zone at about $38 \mathrm{mbsf}$ is marked by the presence of pyritequartz breccia, with anhydrite confined to veins and vugs. This depth is coincident with the possible location of the seafloor surface before the hydrothermal mound formed ("paleoseafloor level" in Fig. 6). 

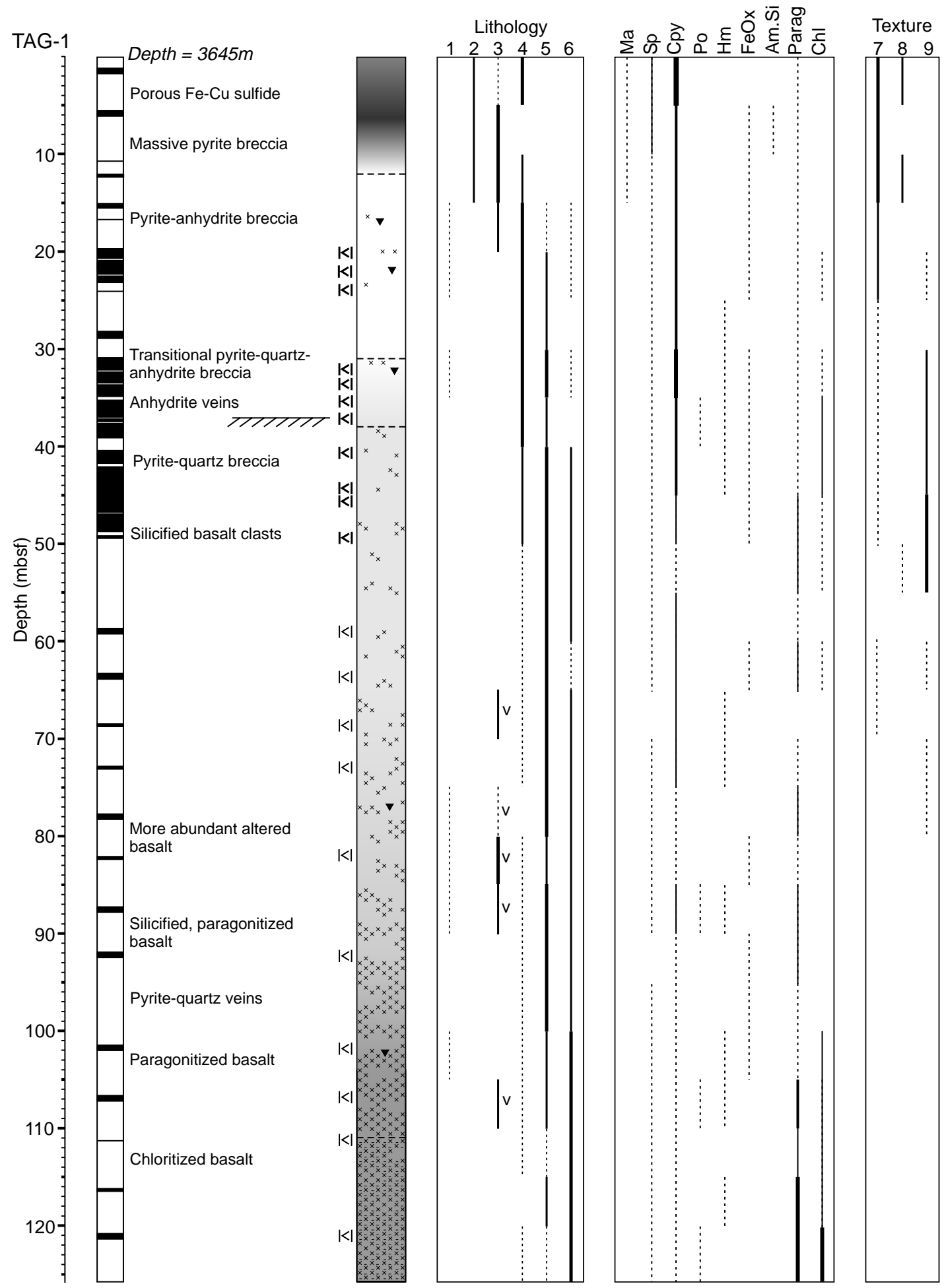

KEY

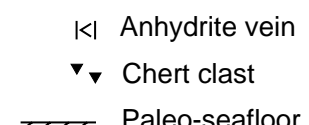

<1 Anhydrite vein

Paleo-seafloor level (see text for explanation)

Figure 6. Vertical distribution of lithology, mineralogy, and texture through the TAG-1 (central mound) composite section. The width of vertical bars is proportional to absolute abundance; dashed line indicates trace occurrence. Horizontal strips next to the vertical scale indicate the proportion of core recovered from each section. Lithology key: $1=\mathrm{Si}-\mathrm{Fe}$ oxyhydroxide; $2=$ porous sulfide; $3=$ sulfide breccia $(\mathrm{v}=$ vein-related); $4=$ sulfide-anhydrite; $5=$ sulfide-quartz; $6=$ altered basalt. Texture key: $7=$ colloform pyrite; $8=$ cryptocrystalline or chalcedonic quartz; $9=$ banded quartz. Mineral abbreviations as in Table 2 . 


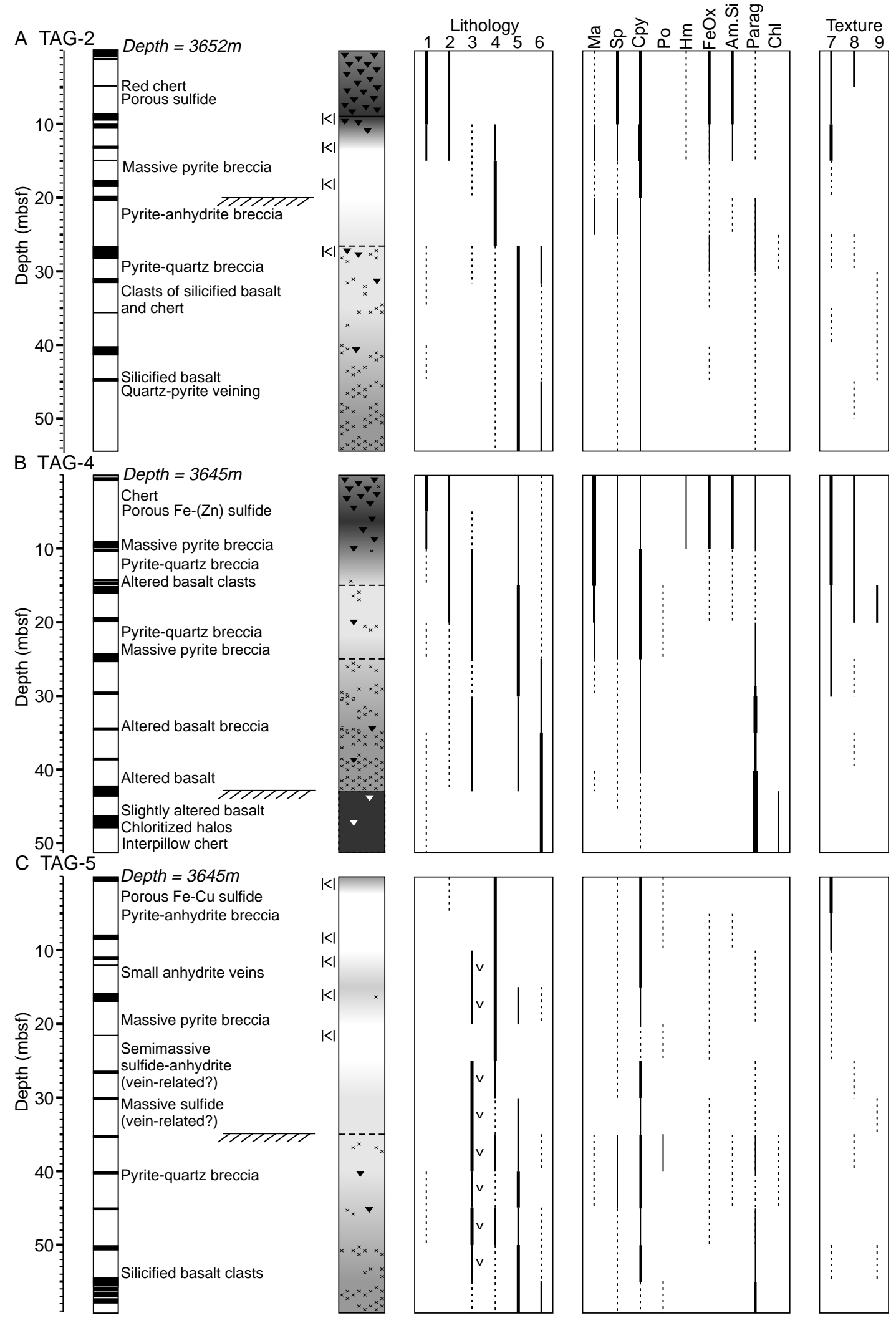

Figure 7. Vertical distribution of lithology, mineralogy, and texture in (A) TAG-2 (Kremlin area); (B) TAG-4 (west); and (C) TAG-5 (north) sections. For explanation, see Figure 6 key and caption. 
Table 5. Depth intervals and estimated total thickness of major lithologic types.

\begin{tabular}{|c|c|c|c|c|}
\hline Lithology & $\begin{array}{l}\text { TAG-1 } \\
\text { Central }\end{array}$ & $\begin{array}{c}\text { TAG-2 } \\
\text { Kremlin }\end{array}$ & $\begin{array}{l}\text { TAG-4 } \\
\text { West }\end{array}$ & $\begin{array}{l}\text { TAG-5 } \\
\text { North }\end{array}$ \\
\hline $\begin{array}{l}\text { Chert and } \\
\text { Fe oxyhydroxide }\end{array}$ & $\overline{0 \mathrm{~m}}$ & $\begin{array}{c}0-9 \mathrm{mbsf} \\
5 \mathrm{~m}\end{array}$ & $\begin{array}{l}0-1 \\
1 \mathrm{~m}\end{array}$ & $\overline{0 \mathrm{~m}}$ \\
\hline Porous sulfide & $\begin{array}{l}0-1 \mathrm{mbsf} \\
1 \mathrm{~m}\end{array}$ & $\begin{array}{l}0-9 \mathrm{mbsf} \\
4 \mathrm{~m}\end{array}$ & $\begin{array}{c}1-15 \mathrm{mbsf} \\
14 \mathrm{~m}\end{array}$ & $\begin{array}{l}0-2 \mathrm{mbsf} \\
2 \mathrm{~m}\end{array}$ \\
\hline Massive pyrite breccia & $\begin{array}{l}1-12 \mathrm{mbsf} \\
11 \mathrm{~m}\end{array}$ & $\begin{array}{l}9-26 \mathrm{mbsf} \\
7 \mathrm{~m}\end{array}$ & $\begin{array}{c}15-42 \mathrm{mbsf} \\
6 \mathrm{~m}\end{array}$ & $\begin{array}{l}2-35 \mathrm{mbsf} \\
17 \mathrm{~m}\end{array}$ \\
\hline $\begin{array}{l}\text { Sulfide-anhydrite } \\
\text { Breccia/semimassive } \\
\text { Anhydrite veins }\end{array}$ & $\begin{array}{l}12-31 \mathrm{mbsf} \\
15 \mathrm{~m} \\
4 \mathrm{~m}\end{array}$ & $\begin{array}{l}9-26 \mathrm{mbsf} \\
10 \mathrm{~m} \\
<1 \mathrm{~m}\end{array}$ & $\begin{array}{l}\overline{0 \mathrm{~m}} \\
0 \mathrm{~m}\end{array}$ & $\begin{array}{l}2-35 \mathrm{mbsf} \\
15 \mathrm{~m} \\
1 \mathrm{~m}\end{array}$ \\
\hline $\begin{array}{l}\text { Pyrite-quartz-anhydrite } \\
\text { (transitional) }\end{array}$ & $\begin{array}{c}31-38 \mathrm{mbsf} \\
7 \mathrm{~m}\end{array}$ & - & - & - \\
\hline $\begin{array}{l}\text { Sulfide-quartz } \\
\text { Breccia } \\
\text { Silicified basalt }\end{array}$ & $\begin{array}{l}38-111 \mathrm{mbsf} \\
35 \mathrm{~m} \\
38 \mathrm{~m}\end{array}$ & $\begin{array}{c}26 \text { mbsf-eoh } \\
>22 \mathrm{~m} \\
>6 \mathrm{~m}\end{array}$ & $\begin{array}{c}15-42 \mathrm{mbsf} \\
16 \mathrm{~m} \\
5 \mathrm{~m}\end{array}$ & $\begin{array}{c}35 \text { mbsf-eoh } \\
>21 \mathrm{~m} \\
>3 \mathrm{~m}\end{array}$ \\
\hline Altered basalt & $111 \mathrm{mbsf}-\mathrm{eoh}$ & $\begin{array}{c}(20 \text { mbsf } \\
\text { Hole 957B) }\end{array}$ & $42 \mathrm{mbsf}-\mathrm{eoh}$ & - \\
\hline $\begin{array}{l}\text { Chloritized basalt } \\
\text { Low-T altered basalt }\end{array}$ & $>15 \mathrm{~m}$ & $\begin{array}{c}0 \mathrm{~m} \\
(>10 \mathrm{~m} \text { in } \\
\text { Hole } 957 \mathrm{~B})\end{array}$ & $\begin{array}{l}>9 \mathrm{~m} \\
>9 \mathrm{~m}\end{array}$ & $\begin{array}{l}0 \mathrm{~m} \\
0 \mathrm{~m}\end{array}$ \\
\hline
\end{tabular}

Notes: Depth below surface (mbsf) based on generalized stratigraphic divisions (Fig. 3); thickness $(\mathrm{m})$ of lithologic subdivisions are estimated from the relative proportions of recovered material. eoh $=$ end of hole $;-=$ not present. $\mathrm{T}=$ temperature .

The paleoseafloor level was estimated for all the drilled regions of the mound by assuming that the seafloor was planar and sloped downwards from the southeastern to the northwestern margins of the mound. The first large $(>5 \mathrm{~cm})$ pieces of brecciated, silicified basalt also appear at about this depth (small clasts are seen as shallow as $16.5 \mathrm{mbsf}$ ). However, between 38 and about $78 \mathrm{mbsf}$, the zone is at least partly of primary hydrothermal precipitation origin (as opposed to the in situ alteration of basalt), based on the presence of cryptocrystalline textures and banding in the quartz (Fig. 6). The proportion of altered basalt increases with depth, particularly below about 78 mbsf. The altered basalt is less intensively silicified below $101 \mathrm{mbsf}$, and at about $111 \mathrm{mbsf}$ the alteration style changes from paragonitization to chloritization. This marks the boundary of the chloritized stockwork (Honnorez et al., Chap. 18, this volume).

\section{Lateral Variations}

Lateral variations in hydrothermal mineralization are at least as great as the vertical variation described above. This is best illustrated by contrasting the TAG-4 section (Fig. 7B) with the other sections. TAG-4 differs from the rest of the mound by the absence of anhydrite, the abundance of sphalerite-marcasite at depth, the presence of altered basalt clasts close to the mound surface, and the less extensively altered basalt basement. Near-surface mineralization takes the form of $\mathrm{Si}-\mathrm{Fe}$ oxyhydroxide and porous $\mathrm{Fe}-(\mathrm{Zn})$ sulfide and silica. This passes with increasing depth to a heterogeneous sequence of pyrite and pyrite-quartz breccia. These lithologies appear to occur as fragmental material, encrusted by late overgrowths of banded pyritemarcasite, sphalerite, and silica. Sphalerite and marcasite are confined to the top $10 \mathrm{~m}$ of the mound elsewhere, but extend here to greater than 30 mbsf. Altered basalt clasts are present within $5 \mathrm{~m}$ of the surface, are scattered throughout the breccia sequence, and increase in size and abundance with depth. At about 42 mbsf there is an abrupt change from hydrothermal breccia to slightly altered basalt with scattered fragments of recrystallized interpillow chert. These features suggest that the western side of the mound has accumulated as talus on the basaltic basement and has experienced only minor, moderate- to low-temperature hydrothermal mineralization.
TAG-5 is dominated by a sequence of massive sulfide and sulfide-anhydrite at least $35 \mathrm{~m}$ thick (Fig. 7C). Texture and sulfide mineralogy of the two types are similar, the main difference being the presence or absence of anhydrite. The vertically discontinuous distribution of anhydrite may be a primary depositional feature, or it may be related to dissolution. The latter possibility would be consistent with the location of TAG-5 close to the edge of the mound. Macroscopic clastic breccia textures are less abundant here than elsewhere in the mound. Further distinctive features of TAG-5 are the abundance of colloform and microcrystalline textures in massive sulfideanhydrite, and the presence of primary pyrrhotite grains. Elsewhere in the mound, pyrrhotite occurs as rare inclusions in pyrite or is pseudomorphed by pyrite; in surface samples it is restricted to sulfide crusts on the flanks of black smoker complex (Tivey et al., 1995).

Near-surface mineralization at TAG-2 differs from TAG-1 by the presence of chert and $\mathrm{Fe}$-oxyhydroxide, and the dominance of $\mathrm{Fe}$ ( $\mathrm{Zn})$ sulfide over $\mathrm{Fe}-\mathrm{Cu}$ sulfide. These differences may be related to the different dynamics and fluid chemistry of the Kremlin white smokers compared to the black smokers near TAG-1. Despite these surface differences, the TAG- 2 section below about 10 mbsf is similar in many respects to TAG-1, although the vertical zonation is compressed somewhat (Fig. 7A). The sulfide-anhydrite zone is thinner, anhydrite veining is poorly developed, and anhydrite is generally less abundant. Pyrite-quartz breccia contains a polymict assemblage of pyrite, chert, altered basalt, and altered pillow breccia. The holes drilled at TAG-2 define the southeasterly extent of the quartz-paragonite stockwork. Altered basalt was recovered in the sulfide-quartz zone in Hole $957 \mathrm{H}$, whereas slightly altered basalt basement was reached at only 20 mbsf in Hole 957B, less than 10 m away.

\section{SULFUR-ISOTOPE COMPOSITION OF SULFIDES}

A total of 66 pyrite, chalcopyrite, and marcasite separates were analyzed from different lithologic types and sulfide generations (Table 6). Samples from between 0.2 to $121 \mathrm{mbsf}$ in TAG-1, TAG-2, TAG-4, and TAG-5 reveal the extent of mound-scale vertical and lateral variation.

Sulfides from within the mound have $\delta^{34} \mathrm{~S}$ ranging from $+4.4 \%$ o to $+8.9 \%$ (mean and standard deviation of $+6.6 \% \circ \pm 0.9 \%$ ). These results slightly expand the range reported for the analysis of bulk powders (Herzig et al., Chap. 4, this volume), and exceed the range reported for surface samples $(+4.1 \%$ o to $+5.8 \%$ o, Lein et al., 1991 ; and $+5.7 \%$ o to $+7.6 \%$, W.C. Shanks, pers. comm.) and for $\mathrm{H}_{2} \mathrm{~S}$ in the black smoker fluids $(+6.6 \%$ to $+7.5 \%$, W.C. Shanks, pers. comm, 1995.)

Average values for each of the four sites are virtually identical. However, the variation between different sulfide generations is greater in TAG-1 (range $+4.4 \%$ o to $+8.6 \%$ ) and TAG- $4(+4.8 \%$ o to $+8.9 \%$ ) than in TAG-2 (range $+6.3 \%$ to $+7.5 \%$ ) or TAG-5 $(+6.1 \%$ o to $+7.9 \%$ ). There are significant differences between the various lithology types (Fig. 8). Sulfides with the lowest $\delta^{34} \mathrm{~S}$ are associated with anhydrite veins (mean $+5.6 \% \circ \pm 0.7 \%$ o). Massive sulfides and pyriteanhydrite breccia show similar frequency distributions. Pyrite-quartz breccia and altered basalt are shifted to higher $\delta^{34} \mathrm{~S}$, and the heaviest sulfides are associated with altered basalt (mean $+8.0 \% \circ \pm 0.7 \%$ o).

In the TAG-1 section, variation between the different zones leads to a general trend of increasing $\delta^{34} S$ with depth (Fig. 9). The lowest values occur in porous sulfide, pyrite breccia, and sulfide-anhydrite breccia. Maximum variability in $\delta^{34} S$ occurs through the sulfide-anhydrite zone and into the transitional zone of pyrite-quartz anhydrite breccia and anhydrite-veining. An increase in $\delta^{34} S$ is seen through the sulfide-quartz zone, and the isotopically heaviest sulfide is present where the sulfide-quartz zone is transitional into altered basalt. Much of the variability observed in TAG-1 is explained by two features: (1) the distribution of isotopically light vein-related mineralization, and 
Table 6. Sulfur-isotope composition of sulfide mineral separates.

\begin{tabular}{|c|c|c|c|c|c|c|}
\hline $\begin{array}{l}\text { Core, section, } \\
\text { interval }(\mathrm{cm})\end{array}$ & Piece & $\begin{array}{l}\text { Depth } \\
\text { (mbsf) }\end{array}$ & Lithology & Mineral & Description & $\begin{array}{l}\delta^{34} \mathrm{~S} \\
(\%)\end{array}$ \\
\hline \multirow{2}{*}{$\begin{array}{l}\text { TAG-1 (Central) } \\
957 \mathrm{~F}-1 \mathrm{~N}-1,19-21\end{array}$} & & & & & & \\
\hline & 5 & 1.17 & Porous $\mathrm{Fe}-\mathrm{Cu}$ & $\underset{\text { Py (cpy) }}{\text { Cpy }}$ & $\begin{array}{l}\text { Massive sulfide (porous) } \\
\text { Massive sulfide (porouss }\end{array}$ & $\begin{array}{l}5.1 \\
6.0\end{array}$ \\
\hline $957 \mathrm{G}-1 \mathrm{~N}-1,17-19$ & 4 & 12.17 & Py breccia & Py & Massive sulfide (clast) & 5.2 \\
\hline $957 \mathrm{G}-3 \mathrm{~N}-1,2-5$ & 1 & 21.00 & Py breccia & Py & Massive sulfide (clast) & 5.8 \\
\hline \multirow[t]{2}{*}{$957 \mathrm{C}-7 \mathrm{~N}-2,85-86$} & $1 \mathrm{G}$ & 21.64 & Py-anhy breccia (v) & Сpy (py) & Dissem. sulfide & 6.4 \\
\hline & & & & Py (cpy) & Massive sulfide (clast) & 7.1 \\
\hline \multirow{2}{*}{$957 \mathrm{C}-7 \mathrm{~N}-2,144-149$} & $1 \mathrm{~K}$ & 22.12 & Py-anhy breccia (v) & Py (cpy) & Dissem. sulfide & 6.6 \\
\hline & & & & Py (cpy) & Vein & 5.1 \\
\hline \multirow{2}{*}{$\begin{array}{l}\text { 957C-9X-1, 7-9 } \\
957 \mathrm{C}-11 \mathrm{~N}-2,70-75\end{array}$} & 2 & 24.40 & Py-anhy breccia & Py & Massive sulfide (clast) & 5.2 \\
\hline & $1 \mathrm{~K}$ & 32.80 & Py-anhy breccia (v) & $\begin{array}{l}\text { Py } \\
\text { Cpy (py) }\end{array}$ & $\begin{array}{l}\text { Massive sulfide (clast) } \\
\text { Vein }\end{array}$ & $\begin{array}{l}5.5 \\
4.4\end{array}$ \\
\hline $957 \mathrm{C}-12 \mathrm{~N}-2,57-59$ & $8 \mathrm{~A}$ & 36.12 & Py-qtz-anhy breccia (v) & Py (cpy) & Vein & 6.4 \\
\hline $957 \mathrm{C}-12 \mathrm{~N}-3,53-56$ & 5 & 36.75 & Py-qtz-anhy breccia & Py & Massive sulfide (clast) & 7.4 \\
\hline $957 \mathrm{C}-14 \mathrm{~N}-1,59-62$ & 8 & 40.79 & Anhy vein & Py (cpy) & Vein & 5.8 \\
\hline $957 \mathrm{C}-15 \mathrm{~N}-1,28-32$ & 4 & 42.43 & Py-qtz breccia & $\mathrm{Py}$ & Massive sulfide & 5.8 \\
\hline $957 \mathrm{C}-15 \mathrm{~N}-2,112-116$ & 6 & 44.11 & Anhy vein & $\begin{array}{l}\text { Cpy } \\
\text { Py }\end{array}$ & $\begin{array}{l}\text { Vein } \\
\text { Vein }\end{array}$ & $\begin{array}{l}5.2 \\
6.3\end{array}$ \\
\hline $957 \mathrm{C}-16 \mathrm{~N}-1,107-111$ & 14B & 47.16 & Py-qtz breccia & Py & Massive sulfide (clast) & 6.4 \\
\hline $957 \mathrm{E}-5 \mathrm{R}-1,32-36$ & 7 & 58.92 & Py-qtz breccia (v) & Py & Massive sulfide (clast) & 7.5 \\
\hline \multirow{3}{*}{$\begin{array}{l}\text { 957E-7R-1, 1-4 } \\
\text { 957E-12R-1, 23-26 }\end{array}$} & 1 & 68.30 & Py-atz breccia & $\begin{array}{l}\mathrm{Py} \\
\mathrm{Py}\end{array}$ & $\begin{array}{l}\text { Vein } \\
\text { Dissen }\end{array}$ & 6.0 \\
\hline & 4 & 92.00 & Altered basalt & $\begin{array}{l}\text { Py } \\
\text { Py }\end{array}$ & $\begin{array}{l}\text { Dissem. sulfide } \\
\text { Massive sulfide }\end{array}$ & $\begin{array}{l}6.7 \\
7.5\end{array}$ \\
\hline & & & & Py & Dissem. (alt. basalt) & 7.0 \\
\hline 957E-15R-1, 15-19 & 4 & 106.64 & Altered basalt & Py & Dissem. (alt. basalt) & 8.6 \\
\hline $957 \mathrm{E}-15 \mathrm{R}-1,35-37$ & 7 & 106.84 & Py-qtz breccia & Py & Massive sulfide (clast) & 7.4 \\
\hline \multirow[t]{2}{*}{ 957E-17R-1, 16-22 } & 3 & 116.17 & Altered basalt & $\begin{array}{l}\text { Py } \\
\text { Py }\end{array}$ & Dissem. (alt. basalt) & $\begin{array}{l}8.1 \\
8.3\end{array}$ \\
\hline & & & (nv-atz hreo & $\begin{array}{l}\text { Py } \\
\text { Py }\end{array}$ & $\begin{array}{l}\text { Vein (alt. basalt) } \\
\text { Massive sulfide (clast) }\end{array}$ & $\begin{array}{l}8.3 \\
8.2\end{array}$ \\
\hline 957E-18R-1, 30-31 & 5 & 120.95 & Py-qtz breccia & Py & Massive sulfide & $\begin{array}{l}8.2 \\
7.3\end{array}$ \\
\hline \multicolumn{7}{|l|}{ TAG-2 (Kremlin) } \\
\hline $957 \mathrm{H}-1 \mathrm{~N}-1,44-47$ & 9 & 9.07 & Py-anhy breccia & Py (сру) & Massive sulfide (clast) & 6.3 \\
\hline $957 \mathrm{~A}-3 \mathrm{X}-1,0-4$ & 1 & 10.00 & Porous $\mathrm{Fe}-(\mathrm{Zn})$ & Py & Massive sulfide (porous) & 6.6 \\
\hline \multirow[t]{2}{*}{$957 \mathrm{H}-2 \mathrm{~N}-1,17-19$} & 4 & 13.37 & Py-anhy breccia & Py & Massive sulfide (clast) & 6.9 \\
\hline & & & & Py (cpy) & Dissem. sulfide & 6.8 \\
\hline \multirow[t]{2}{*}{$957 \mathrm{H}-3 \mathrm{~N}-1,40-44$} & 9 & 18.10 & Py-anhy breccia & $\mathrm{Py}$ & Massive sulfide (clast) & 6.4 \\
\hline & & & & Py & Dissem. sulfide & 7.5 \\
\hline \multirow[t]{2}{*}{$957 \mathrm{H}-5 \mathrm{~N}-1,47-50$} & $5 \mathrm{~B}$ & 26.98 & Py-qtz breccia & Py & Massive sulfide (clast) & 7.5 \\
\hline & & & & Py & Dissem. sulfide & 7.0 \\
\hline \multicolumn{7}{|l|}{ TAG-4 (West) } \\
\hline $957 \mathrm{~K}-1 \mathrm{X}-1,22-23$ & 4 & 0.21 & Porous Fe-(Zn) & Py & Massive sulfide (porous) & 6.2 \\
\hline $957 \mathrm{M}-2 \mathrm{R}-1,11-14$ & 3 & 9.40 & Py-qtz breccia & $\begin{array}{l}\mathrm{Ma} \\
\mathrm{Cpy}\end{array}$ & $\begin{array}{l}\text { Massive sulfide (porous) } \\
\text { Massive sulfide (clast) }\end{array}$ & $\begin{array}{l}4.8 \\
7.1\end{array}$ \\
\hline & & & & $\begin{array}{l}\text { Cpy } \\
\text { Py }\end{array}$ & Massive sulfide (clast) & 6.8 \\
\hline $957 \mathrm{~K}-2 \mathrm{~N}-1,25-27$ & 7 & 10.24 & Py breccia & Py & Massive sulfide (clast) & 7.0 \\
\hline & & & & Py (ma) & Crust & 5.1 \\
\hline 957M-3R-1, 130-137 & 30 & 15.60 & Py-qtz breccia & Py (cpy) & Dissem. sulfide & 6.8 \\
\hline & & & & Py $(\mathrm{n}$ & & 6.2 \\
\hline 957M-4R-1, 55-58 & 12 & 19.84 & Py-qtz breccia & Py (cpy) & Dissem. sulfide & 5.7 \\
\hline & & & & $\mathrm{Py}$ & Dissem. (alt. basalt) & 8.9 \\
\hline 957M-5R-1, 108-111 & 18 & 25.37 & Py-qtz breccia & Py & Massive sulfide & 7.1 \\
\hline & & & & $\begin{array}{l}\text { Py } \\
P y\end{array}$ & Massive sulfide (clast) & 8.3 \\
\hline 957M-9R-1, 14-16 & 3 & 42.42 & Altered basalt & Py & $\begin{array}{l}\text { Crust } \\
\text { Dissem. (alt. basalt) }\end{array}$ & $\begin{array}{l}6.2 \\
7.3\end{array}$ \\
\hline TAG-5 (North) & & & & & & \\
\hline $1,60-63$ & 11 & 0.60 & Py-anhy breccia & Py & Dissem. sulfide & 7.1 \\
\hline $957 \mathrm{O}-3 \mathrm{R}-1,2-4$ & 1 & 10.90 & Py-anhy breccia & Py & Massive sulfide (clast) & 6.9 \\
\hline & & & & Сpy (py) & Massive sulfide & 6.8 \\
\hline 957P-3R-1, 1-4 & 1 & 1.90 & S-mass. py-anhy & Py & Massive sulfide & 7.0 \\
\hline 957O-4 & 7 & 16 & Mass & $\begin{array}{l}\text { Py } \\
\text { Py }\end{array}$ & $\begin{array}{l}\text { Dissem. sulfide } \\
\text { Massive sulfide (clast) }\end{array}$ & $\begin{array}{l}6.9 \\
6.8\end{array}$ \\
\hline $9070-4$ & 1 & & Nite & Py (cpy) & Massive sulfide & $\begin{array}{l}0.0 \\
6.5\end{array}$ \\
\hline 957P-7R-1, 1-3 & 1 & 35.10 & Py-qtz brecc & Py (cpy) & Dissem. sulfide & 7.5 \\
\hline 957P-9R-1, 0-9 & 1 & 40.10 & Py-qtz brecc & $\mathrm{Py}$ & Massive sulfide (clast) & 7.9 \\
\hline 957P-10R-1, 14-16 & 4 & 45.24 & S-mass. py-anhy & Py & Dissem. sulfide & 6.5 \\
\hline & & & & Py (cpy) & & 6.4 \\
\hline & & & & & Dissem. sulfide & 6.4 \\
\hline 957P-11R-1, 41-47 & 9 & 50.51 & & Py & Massive sulfide (clast) & 7.1 \\
\hline 957P-11R-1, 60-62 & 12 & 50.66 & py-anhy & Py & Dissem. sulfide & 6.1 \\
\hline $957 \mathrm{P}-12 \mathrm{R}-4,60-63$ & 6 & 57.68 & Massive py & Py & Massive sulfide & 6.4 \\
\hline
\end{tabular}

Notes: Mineral abbreviations as Table 2. S-mass. = semi-massive; dissem.= disseminated; alt. = altered. (v) in lithology indicates sample veined by anhydrite. Mineral separate purity $>90 \%$; in parentheses $10 \%$ to $50 \%$.

(2) the isotopic heterogeneity of clasts in the breccia. Vein-related $\mathrm{Fe}-\mathrm{Cu}$ sulfide mineralization is systematically $1.1 \%$ o to $1.5 \%$ o lighter than either sulfide clasts or matrix in the adjacent host breccia. Pyrite clasts in the breccia range from $+5.2 \%$ o to $+7.4 \%$; this variation is much greater than that within the matrix. The general trend of increasing $\delta^{34} \mathrm{~S}$ with depth is explained by high $\delta^{34} \mathrm{~S}$ of disseminated pyrite in altered basalt clasts and pyrite mineralization in the quartzparagonite stockwork. Pyrite in clasts of altered basalt is up to $1.2 \%$ o heavier than pyrite in the surrounding pyrite-quartz breccia.
The other vertical sections display no obvious $\delta^{34} S$ variation with depth. The isotopically lightest generations are generally found in porous massive sulfides near the surface. The higher $\delta^{34} \mathrm{~S}$ of the pyritequartz breccia at depth is a result of the presence of altered basalt clasts. Disseminated pyrite in altered basalt is as much as $3.3 \%$ heavier than pyrite in the pyrite-quartz breccia.

Anhydrite separates extracted from breccia matrix and vein mineralization were also analyzed (Table 7). The ten samples range from $+19.2 \%$ o to $+20.9 \%$, although most are close to the seawater value of 
A
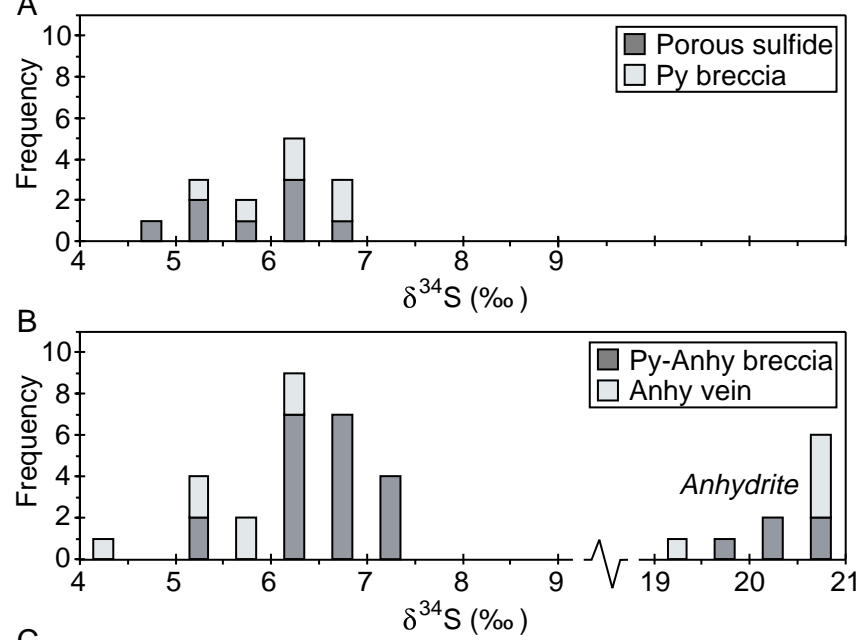

C

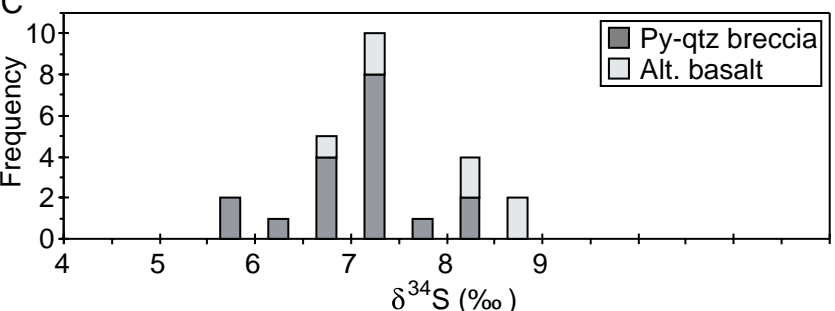

Figure 8. Sulfur-isotope data for sulfide and anhydrite from the different lithologic types encountered in the TAG mound. (A) Massive sulfide (porous sulfide, pyrite breccia); (B) sulfide-anhydrite (pyrite-anhydrite breccia, anhydrite vein-related mineralization); (C) sulfide-quartz (pyrite-quartz breccia and altered basalt).

$21 \%$ (frequency distribution in Fig. 8A). No systematic variations between sites, with depth, or between matrix and vein associations are seen.

\section{DISCUSSION \\ Sulfide Geochemistry}

Sulfides from the interior of the TAG mound are generally depleted in trace elements when compared to the TAG surface hydrothermal precipitates analyzed by Tivey et al. (1995), or compared to most other seafloor sulfide deposits (e.g., Hannington et al., 1991). This is apparent in the bulk geochemical analyses (Fouquet et al., Chap. 27, this volume; Hannington et al., Chap. 28, this volume) and in the microprobe analyses presented here. The exception is cobalt, which is enriched in pyrite from within the mound compared to surface hydrothermal precipitates. Co is readily accommodated in pyrite by lattice substitution for Fe (Bralia et al., 1979). Fouquet et al. (Chap. 27, this volume) describe a statistically significant association of Co with $\mathrm{Se}$ in bulk geochemical analyses, giving a geochemical signature characteristic of high-temperature hydrothermal activity. They also describe a general trend of increasing $\mathrm{Co}$ and Se with depth. High Co concentration detected by microprobe in pyrite from the quartz-paragonite stockwork are probably related to high-temperature mineralizing conditions and the presence of Co-bearing fluids; oxygen-isotope data indicate that the alteration (and, by inference, mineralization) took place at temperatures of $300^{\circ}-360^{\circ} \mathrm{C}$ (Alt and Teagle, Chap. 21 , this volume), while fluid inclusion data from quartz give trapping temperatures as high as $390^{\circ} \mathrm{C}$ (Petersen et al., Chap. 13, this volume). Oscillatory zonation of $\mathrm{Co}$ in the pyrite records fluctuating physicochemical conditions as hydrothermal flow and mixing pathways evolve with time.

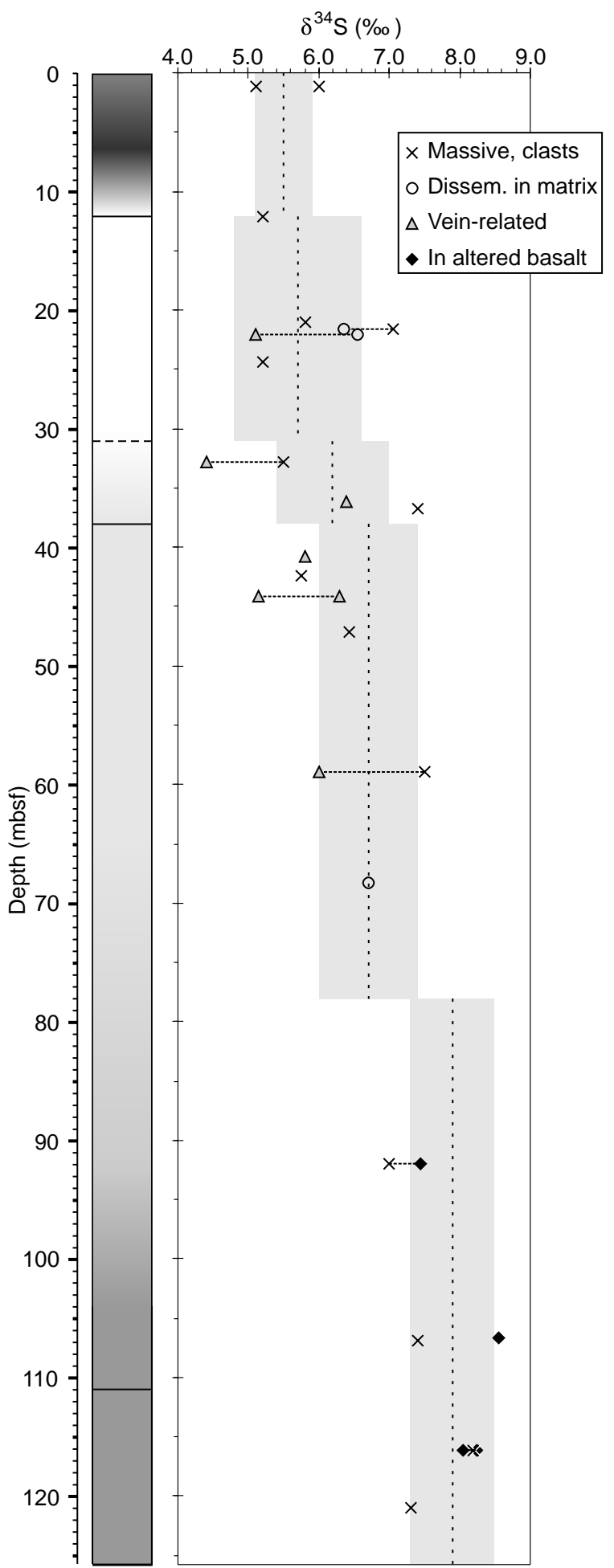

Figure 9. A vertical sulfur-isotope profile for the TAG-1 (central mound) section. Tie lines emphasize analyses from spatially related sulfide generations within the same centimeter-sized sample (e.g., a vein selvage and the adjacent breccia). Vertical dashed lines and shaded region indicate mean and standard deviation for the analyses in each zone; dissem. = disseminated. 
Table 7. Sulfur-isotopic composition of anhydrite from veins and breccia matrix.

\begin{tabular}{|c|c|c|c|c|c|c|}
\hline $\begin{array}{l}\text { Core, section, } \\
\text { interval }(\mathrm{cm})\end{array}$ & Piece & $\begin{array}{l}\text { Depth } \\
\text { (mbsf) }\end{array}$ & Lithology & Mineral & Description & $\delta^{34} \mathrm{~S}(\% o)$ \\
\hline \multicolumn{7}{|l|}{ TAG-1 (Central) } \\
\hline $957 \mathrm{C}-7 \mathrm{~N}-2,144-149$ & $1 \mathrm{~K}$ & 22.12 & Py-anhy breccia (v) & Anhy & Matrix & 20.8 \\
\hline $957 \mathrm{C}-11 \mathrm{~N}-2,70-75$ & $1 \mathrm{~K}$ & 32.80 & Py-anhy breccia (v) & Anhy & Vein & 20.7 \\
\hline $957 \mathrm{C}-15 \mathrm{~N}-2,112-116$ & 6 & 44.11 & Anhy vein & Anhy & Vein & 20.8 \\
\hline 957E-7R-1, 1-4 & 1 & 68.30 & Py-qtz breccia & Anhy & Vein & 19.2 \\
\hline 957E-18R-1, 30-31 & 5 & 120.95 & Py-qtz breccia & Anhy & Vein & 20.9 \\
\hline \multicolumn{7}{|l|}{ TAG-2 (Kremlin) } \\
\hline $957 \mathrm{H}-1 \mathrm{~N}-1,44-47$ & 9 & 9.07 & Py-anhy breccia & Anhy & Matrix & 20.2 \\
\hline $957 \mathrm{H}-5 \mathrm{~N}-1,47-50$ & $5 B$ & 26.98 & Py-qtz breccia & Anhy & Vein & 20.6 \\
\hline \multicolumn{7}{|l|}{ TAG-5 (North) } \\
\hline 957P-1R-1, 60-63 & 11 & 0.60 & Py-anhy breccia & Anhy & Matrix & 20.9 \\
\hline $957 \mathrm{O}-3 \mathrm{R}-1,2-4$ & 1 & 10.90 & Py-anhy breccia & Anhy & Matrix & 19.8 \\
\hline 957P-11R-1, 60-62 & 12 & 50.66 & S-mass. py-anhy & Anhy & Matrix & 20.4 \\
\hline
\end{tabular}

Notes: Abbreviations as in Table 6.

The low Se concentrations in mound sulfides (Fouquet et al., Chap. 27, this volume; Hannington et al., Chap. 28, this volume) contrast with mound surface mineralization around the active black smoker complex, where up to $0.28 \mathrm{wt} \%$ Se was found in chalcopyrite (Tivey et al., 1995). An empirical relationship between Se and high temperature, end-member black smoker mineralization has been documented at other sites (e.g., Auclair et al., 1987; Fouquet et al., 1993). Huston et al. (1995) propose that variation in the Se-content of sulfides is not due to temperature but to varying $\Sigma \mathrm{Se} / \Sigma \mathrm{S}$ ratio of the hydrothermal fluid, which is influenced by mixing with seawater or by prior precipitation of Se in sulfides. Mixing between end-member hydrothermal fluids and entrained seawater or shallow-circulated seawater-hydrothermal solutions (see sulfur-isotope discussion, below) could lower the $\Sigma \mathrm{Se} / \Sigma \mathrm{S}$ ratio of the fluids circulating within the mound and lead to precipitation of Se-poor sulfides (Fouquet et al., Chap. 27, this volume). The chalcopyrite analyzed from within the mound is probably unrelated to the feeders for the active black smoker complex which, as in the chimneys, would be expected to contain significant trace Se (Auclair et al., 1987; Tivey et al., 1995). This constrains the black smoker feeder system to a localized zone beneath the black smoker complex, and further suggests that the black smoker fluids that vent from the black smoker complex pass through the shallow (less than about 120 mbsf) stockwork feeder and mound virtually unmodified by interaction with the mound circulation and entrainment system. Mineralization and alteration around the focused upflow zone might form a relatively impermeable region that has sealed the black smoker feeders from the rest of the mound circulation system.

\section{Sulfur-Isotope Variation}

The TAG hydrothermal mound is remarkable for the high sulfide $\delta^{34} \mathrm{~S}$ compared to most other deposits from sediment-starved midocean ridge axial and off-axial settings in the Atlantic and Pacific (Fig. 10). Data for sulfides from the 13 deposits compiled in Figure 10 range from $-0.8 \%$ o to $+6.2 \%$ (mean $+3.3 \%$ $\pm 1.2 \%$; $\mathrm{N}=399$ ). TAG sulfides reported here are shifted some $3 \%$ o higher than the "average" mid-ocean ridge deposit. Any model must explain why sulfides in the TAG mound contain high $\delta^{34} \mathrm{~S}$ and account for the variations detected in different parts of the mound and between the various sulfide generations.

The $\delta^{34} \mathrm{~S}$ of $\mathrm{H}_{2} \mathrm{~S}$ in deep upwelling hydrothermal fluids is dominated by $\mathrm{S}$ leached from basalt $(0.1 \%$; Sakai et al., 1984) modified by a small component derived from seawater sulfate (21\%o; Rees et al., 1978). Sulfate may be reduced by $\mathrm{Fe}^{2+}$ in basalt (Shanks et al., 1981) or by the conversion of primary MORB pyrrhotite to pyrite (Shanks and Seyfried, 1987). It is predicted that end-member hydrothermal fluids have a basalt-dominated isotopic signature (Bowers, 1989 ) and leave the deep (approximately 1.7 to $2.3 \mathrm{~km}$ ) hydrothermal reaction zone with a relatively constant sulfur-isotopic composition of around $1 \%$ o to $2 \%$. Assuming that this is true of all mid-ocean ridge hydrothermal systems, then the high $\delta^{34} S$ and variability recorded in TAG sulfides requires further incorporation of seawaterderived sulfur. This could occur by sulfate reduction: (1) within the hydrothermal deposit (e.g., Woodruff and Shanks, 1988); or (2) in a shallow (less than about $500 \mathrm{~m}$ deep) seawater-hydrothermal circulation system beneath the deposit (Janecky and Shanks, 1988).

The drilling results demonstrate that seawater is entrained into the mound and stockwork to form anhydrite at depths of at least $125 \mathrm{mbsf}$. Reduction of sulfate in the seawater or in anhydrite must be considered as a possible mechanism to generate high $\delta^{34} \mathrm{~S}$. It has been argued that the kinetics of seawater sulfate reduction at hydrothermal temperatures (i.e., around $350^{\circ} \mathrm{C}$ ) are too slow to have a major effect on the isotopic composition of vent fluids or chimney sulfides because of the high flow rates through the chimney (Bluth and Ohmoto, 1988; Woodruff and Shanks, 1988). The longer residence time of fluids in a large mound such as TAG might lead to more extensive local sulfate reduction: sulfur and oxygen isotope composition of anhydrite within the mound suggests that minor sulfate reduction is taking place (Chiba et al., Chap. 6, this volume). However, incremental reaction modeling shows that the finite reducing potential of the hydrothermal fluid cannot generate $\delta^{34} \mathrm{~S}$ heavier than about $4.5 \%$, regardless of mixing pathways (Janecky and Shanks, 1988). Sulfate reduction within the TAG mound is therefore sufficient to explain the variations seen within massive sulfide clasts, or between veins and breccia. However, processes within the mound cannot explain the generally high $\delta^{34} \mathrm{~S}$ of TAG and would anyway be inconsistent with increasing $\delta^{34} S$ in the stockwork beneath the mound.

Janecky and Shanks (1988) propose that the most likely process to generate a large (greater than about $3 \%$ ) increase in fluid $\delta^{34} \mathrm{~S}$ is sulfate reduction in a shallow hydrothermal circulation system developed around the hydrothermally altered feeder zone beneath the deposit. Sulfate reduction is driven by the oxidation of ferrous iron released when olivine and pyroxene are altered to chlorite. Incipient alteration reactions in the feeder zone could explain the spatial and temporal variations described from most seafloor deposits. In TAG, the same mechanism would explain the high $\delta^{34} S$ of sulfides $(+9 \%$ ) associated with altered basalt and localized to the stockwork. However, Janecky and Shanks (1988) point out that sulfate reduction in the stockwork will have a negligible effect on the bulk sulfur-isotopic composition of large $\left(>10^{6} \mathrm{t}\right)$ sulfide deposits because of the limited volume of basalt available in the feeder zone. For a large deposit, the limited potential for sulfate reduction in the shallow subsurface tends to homogenize the sulfur-isotopic composition of the deposit toward the deep hydrothermal end-member composition. This idea might be particularly applicable to the TAG mound because of the large size and long (at least 20,000 yr), multistage history of hydrothermal activity. Local faulting or intrusion of dykes might allow sulfate reduction to continue by exposing the fluids to fresh basalt, but the possibility can be ruled out because these processes would have a major 


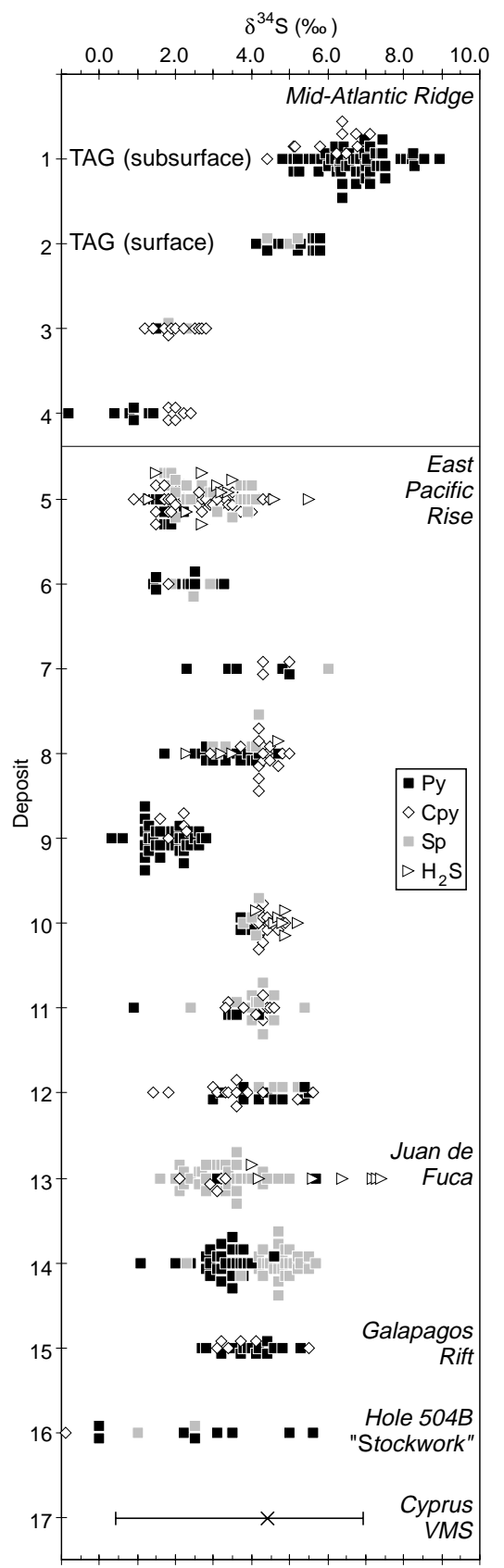

Figure 10. Summary of sulfur-isotopic variation in mid-ocean ridge seafloor sulfide deposits. Deposit locations: (1) TAG subsurface (this report); (2) TAG surface (Lein et al., 1991); (3) Snakepit (Kase et al., 1990); (4) Broken Spur (Duckworth et al., 1995); (5) EPR $21^{\circ} \mathrm{N}$ (Zierenberg et al., 1984; Woodruff and Shanks, 1988); (6) EPR $21^{\circ} \mathrm{N}$ Cyamex zone (Hekinian et al., 1980; Arnold and Sheppard, 1981); (7) Green Seamount, EPR $21^{\circ} \mathrm{N}$ (Alt, 1988); (8) EPR $13^{\circ} \mathrm{N}$ (Bluth and Ohmoto, 1988); (9) EPR $13^{\circ} \mathrm{N}$ Off-axial (Fouquet et al., in press); (10) EPR $11^{\circ} \mathrm{N}$ (Bluth and Ohmoto, 1988); (11) EPR $18^{\circ} \mathrm{S}$ (Marchig et al., 1990); (12) EPR $21^{\circ} \mathrm{S}$ (Marchig et al., 1990); (13) S. Juan de Fuca (Shanks and Seyfried, 1987); (14) Axial Seamount, Juan de Fuca Ridge (Hannington and Scott, 1988); (15) Galapagos Rift (Knott et al., 1995); (16) Hole 504B "stockwork" (Alt et al., 1989); (17) Cyprus VMS deposit, range and average of 53 analyses (Hutchinson and Searle, 1971; Johnson, 1972; Lydon, 1984). effect on the local permeability and flow pathways, making it unlikely that upflow could remain focused at the same point-source.

The heavy isotopic signature of the TAG fluids and sulfide precipitates was probably inherited deeper in the hydrothermal upflow system. The best estimate of a deep end-member source isotopic composition for the TAG hydrothermal system is about $+5.5 \%$, a value derived from the lowest measured values from sulfide associated with veining. This distinguishes TAG from many other seafloor hydrothermal deposits where the minimum sulfide $\delta^{34} \mathrm{~S}$ is closer to the predicted source fluid value of approximately $1.5 \%$ (Fig. 10). We conclude that the general high $\delta^{34} \mathrm{~S}$ of TAG sulfides was generated by processes occurring deeper in the hydrothermal circulation system. This apparently distinguishes TAG from most other seafloor hydrothermal systems, and it implies some unique feature in the permeability structure of the crust that focuses a "point-source" upflow system from a deep reaction zone where reduction of seawater sulfate has generated a large reservoir of basalt containing sulfide with high $\delta^{34} \mathrm{~S}$.

A possible analogue of the TAG scenario has been described from fossil crust in the Cyprus ophiolite. Massive sulfide deposits, stockwork feeder zones, and the epidosites in the deep reaction zones all have a relatively uniform $\delta^{34} \mathrm{~S}$ (Alt, 1994). In contrast, the deep crust section from Hole 504B shows increasing $\delta^{34} \mathrm{~S}$ in the mineralized zone compared with lower values in the deep reaction zone (Alt et al., 1989), which is more like the conceptual model for sulfur isotope systematics in many other mid-ocean ridge systems.

Superimposed on the isotopically heavy hydrothermal source are the effects of sulfate reduction by a shallow circulation system developed around the stockwork, which directly contributes high $\delta^{34} S$ to sulfides in this zone, and provides a fluid component with higher $\delta^{34} \mathrm{~S}$ (approximately $+9 \%$ ). Mixing between the end-member fluid and this modified shallow circulated fluids within the deposit explains the variability measured in different sulfide generations. Further heterogeneity within the mound could be introduced by in situ sulfate reduction.

\section{The Growth and Evolution of the TAG Mound Near-Surface Sulfide Mineralization}

Fine grain size, abundance of primary sulfide deposition textures, and lack of oxidation indicate that porous $\mathrm{Fe}-\mathrm{Cu}$ sulfide formed recently at or near the mound surface by growth into open space. Mineral textures and trace element geochemistry suggest formation as porous crusts, under conditions of diffuse, high-temperature hydrothermal flow (Hannington et al., 1995; Tivey et al., 1995). The mineralization preserves a general prograde assemblage: a foundation of colloform pyrite precipitates form from diffuse flow at moderate temperatures (approximately $250^{\circ}$ to $300^{\circ} \mathrm{C}$ ), followed by insulation and channeling of flow into interconnected pore spaces. This leads to a progressively higher-temperature $\left(300^{\circ}\right.$ to $\left.>350^{\circ} \mathrm{C}\right)$ assemblage of well crystallized pyrite, sphalerite with a moderate Fe-content, and chalcopyrite. These conditions are consistent with the proximity of the black smoker complex and observation of localized diffuse black smoker venting from the mound surface. However, the low Se content suggests that, unlike the focused end-member fluids which form the black smoker complex, the high-temperature mineralizing solution responsible for the porous sulfides has been modified by some degree of mixing with seawater or seawater-hydrothermal solutions during its circulation through the mound.

The pyrite-sphalerite-silica ( \pm chalcopyrite-marcasite) assemblage observed in porous $\mathrm{Fe}$-(Zn) sulfide forms under distinctly different physicochemical conditions. In TAG-2, these near-surface porous sulfides probably precipitate from the same evolved Zn-rich white-smoker fluid that vents from the white smoker chimneys. In contrast, the more marcasite-rich, oxidized Fe-Zn-sulfide-silica assemblage present near the surface and at depth in TAG-4 is probably due to localized conductive cooling of hydrothermal fluid and entrainment of seawater as evidenced by the low conductive heat flow measured in this area (Becker and Von Herzen, 1996). Minor oxida- 
tion of sulfide generates the low $\mathrm{pH}$ conditions favorable for marcasite precipitation (Murowchick and Barnes, 1986).

\section{Formation of Pyrite and Pyrite-Anhydrite Breccias}

Three processes are envisaged for the formation of the compact granular pyrite clasts that are abundant in pyrite and pyrite-anhydrite breccia. These are (1) recrystallization of fragmental surface material; (2) in situ nucleation and growth; and (3) reworking of veinrelated mineralization. The simplest explanation is hydrothermal recrystallization during burial of porous sulfides which formed at the mound surface and became fragmented by collapse and mass wasting. Recrystallization obscures the primary colloform and spheroidal textures, and homogenizes the composition: marcasite is inverted to pyrite; chalcopyrite and sphalerite are dissolved and replaced by pyrite leaving only remnant inclusions. Recrystallization seems to have less effect on the sulfur-isotope composition, but might explain low trace element contents. Clasts with probable recrystallized origin have low Co and low $\delta^{34} \mathrm{~S}$. In situ nucleation and growth probably best explains the nodular clasts in pyrite-anhydrite breccia (as noted earlier, the term "clast" in this context has a morphologic rather than genetic meaning). Evidence for in situ growth is seen in the Co-rich, zoned generations of coarse pyrite that develop concentrically around a microporous core. A simple mechanism of pyrite ( \pm chalcopyrite) nucleation followed by sequential overgrowth in the anhydrite matrix can explain the nodular morphology. This makes it unnecessary to cite processes such as corrosion or rounding during transportation (for which there is no microtextural evidence) to explain the rounded morphology of nodular clasts. A third origin of massive sulfide clasts is from subsurface vein-related massive sulfide selvages and halos that develop along the vein margins. The halos are commonly fractured and brecciated into angular pieces. Further disruption, for example through the dissolution of supporting anhydrite, could remove the fragmental material from its original vein context, and results in irregular, angular massive pyrite clasts.

Other clast types within the breccia have a less ambiguous provenance. Angular pieces of bladed chalcopyrite or red chert are similar to material formed at the surface, and presumably originated as fragmental material on the mound surface. Red chert is taken to be diagnostic of precipitates that originally formed very near to the mound surface. Subsurface oxidation of Fe occurs through the sulfate reduction reaction. According to calculations by Tivey et al. (1995), hematite can precipitate at high temperature with a minimum of mixing, and it is locally seen within the mound as inclusions in sulfide or disseminated in anhydrite veins. However, precipitation as red chert is unlikely because conductive cooling is necessary to precipitate amorphous silica.

Incorporation of surface material at depth is readily explained by burial beneath further surface precipitates. Pyrite-quartz and silicified basalt in the pyrite and pyrite-anhydrite breccia also appear fragmental in origin, apparently derived from the underlying pyritequartz breccia zones. Explaining how material from deeper parts of the mound (i.e., altered basalt) could be transported to higher levels is more difficult, unless the relief of the mound and seafloor was once greater than it is now.

Anhydrite textures in the breccia matrix are mostly consistent with an in situ development. Pyrite-anhydrite breccia is matrix supported and the matrix contains abundant anhydrite. Sulfide is minor and interstitial to anhydrite grains. There is no textural evidence to suggest that the anhydrite could have replaced a pre-existing matrix, and the interlocking anhydrite grains did not grow by filling cavities or fissures. The only remaining explanation for the matrix supported texture is the in situ precipitation of anhydrite by displacement of surrounding grains or clasts of sulfide, thus causing the mound to expand internally. Fluid overpressure could possibly cancel the effect of several tens of meters of overburden, which would otherwise prevent free crystal growth. It appears that the anhydrite provides a frame- work for the formation of interstitial disseminated sulfide as hydrothermal fluids percolate through the intergranular porosity. Scattered sulfide grains and microcrystalline aggregates become progressively coarser grained and the aggregates become interconnected to ultimately form semimassive sulfide-anhydrite. During the long, multistage history of the TAG mound, collapse (through anhydrite dissolution) and reactivation (through anhydrite precipitation) could lead to significant mound growth, disruption, and uplift of older breccia fragments and pieces of altered basalt.

\section{Formation of Anhydrite Veining}

Anhydrite veins seem to form by open-space filling in fissures and fractures. The veins provide a channel to focus hydrothermal fluids, and the permeability characteristic of the host lithology controls the extent of veining and the nature of vein-related sulfide mineralization. Veins in the permeable sulfide-anhydrite zone are small and lack well-defined bands or borders of sulfide mineralization. This is because flow in the vein infiltrates the porous anhydrite matrix. Veinrelated $\mathrm{Cu}-\mathrm{Fe}$ sulfide mineralization is thus disseminated throughout the matrix or encrusted on nearby sulfide clasts. The lower permeability of pyrite-quartz vein walls confines fluid to the vein, and results in sulfide mineralization along the vein walls. The complex banding and vuggy nature of some veins indicate multiple stages of opening, sulfide mineralization, anhydrite deposition, and anhydrite dissolution. Sulfide mineralogy and S-isotopes indicate presumed high-temperature formation from near end-member fluid composition. However, the low Se in sulfide mineralization would suggest that the veins were not the main feeders to the black smoker complex. It appears that they acted as pathways for the modified high-temperature fluids that circulate through the central body of the mound.

\section{Formation of Pyrite-Quartz Breccia}

Pyrite-quartz breccia incorporates clasts of pyrite, chert, and altered basalt. In the upper parts of the pyrite-quartz zone, there is evidence that pyrite-quartz breccia develops by the modification of existing pyrite-anhydrite breccia through the simple dynamic replacement of the anhydrite matrix by quartz aggregates. Locally, openspace deposition of banded quartz in cavities proceeds via amorphous silica or cryptocrystalline quartz precursors. The vuggy appearance and development of polygonal aggregates of quartz might be a result of a small volume decrease during hydrothermal recrystallization of cryptocrystalline and microcrystalline quartz. The vugs are probably the sites of later sulfide or anhydrite deposition. Relationships between pyrite and quartz are confused by mutual intergrowth and replacement. These processes combine to form a matrix of intergrown pyrite and quartz with variable texture and grain size. Further complexity is introduced by replacement of the pyrite-quartz by sulfide mineralization related to late crosscutting anhydrite veins.

Most of the sulfide-quartz zone is beneath the inferred paleoseafloor level, assuming an originally planar, sloping surface. The depth of the basalt basement is only known at the edge of the mound and in those holes (957B and 957M), which reached slightly altered basalt. Therefore, it is very difficult to accurately locate where the hydrothermal mound (formed by hydrothermal mineral precipitation) ends and the stockwork (formed by alteration of basalt basement) begins. Honnorez et al. (Chap. 18, this volume) address this in more detail. For example, the TAG mound might be superimposed on a pillow mound like those seen in the surrounding area (Rona et al., 1993b), or faulting may have displaced the basement to different levels (as suggested by Fouquet et al., Chap. 27, this volume).

The presence of altered basalt and an increase in size and abundance of remnant altered basalt at depth indicates that a large proportion of the pyrite-quartz zone was originally basalt basement. Many of the textures and pyrite-quartz relationships described for pyritequartz breccia could also proceed from a basalt precursor which is al- 
tered, replaced, veined, and generally overprinted by quartz-pyrite mineralization (Honnorez et al., Chap. 18, this volume). The exception is the open-space deposition of banded quartz. However, the relatively small proportion of this texture, its restriction to the upper levels of the pyrite-quartz zone ( $<78 \mathrm{mbsf}$ ), and its patchy development would be consistent with open space filling in the interstices between pillows, between blocks of basalt rubble, or in fissures that have opened in the basement.

\section{CONCLUSIONS}

The growth and evolution of the TAG hydrothermal mound occurs by a combination of the following processes: (1) surface hydrothermal mineralization of $\mathrm{Fe}-\mathrm{Cu}$ sulfide, $\mathrm{Fe}-(\mathrm{Zn})$ sulfide and $\mathrm{Si}-\mathrm{Fe}-$ oxyhydroxides in the form of porous blocks or crusts; (2) modification of surface material within the mound by recrystallization and mineral dissolution; (3) hydrothermal mineralization within the mound forming $\mathrm{Fe}-\mathrm{Cu}$ sulfides, anhydrite and quartz; and (4) the progressive alteration and eventual assimilation of basalt in the underlying basement.

The porous, $\mathrm{Cu}$ - and $\mathrm{Zn}$-rich products of surface mineralization are confined to the upper $10 \mathrm{~m}$ of the mound. Hydrothermal modification within the mound recrystallizes pyrite and silica phases. Chalcopyrite and sphalerite are dissolved and the $\mathrm{Cu}$ and $\mathrm{Zn}$ mobilized to reprecipitate as surface sulfides. Internal precipitation of hydrothermal sulfides, quartz, and anhydrite occurs by a combination of openspace filling, replacement and displacement. The formation of anhydrite as a breccia matrix may lead to a volume increase within the mound and provide the matrix for the precipitation of sulfide or quartz. The pervasive alteration of basalt in the stockwork zone underlying the mound ultimately produces a pyrite-quartz assemblage indistinguishable from hydrothermal pyrite-quartz breccia. Much of the pyrite-quartz zone may have originated in this way.

The main contributory factors driving the precipitation, modification, and alteration processes in the TAG mound are the unusually long-lived focusing of hydrothermal upflow at a point source, the size of the mound (which permits long fluid residence times and internal circulation), and the effects of seawater entrainment and anhydrite precipitation inside the mound. Other inferred contributory factors include locally developed retrograde reactions such as the dissolution of anhydrite and sulfide, and physical disruption of the mound and underlying basement by tectonic activity, collapse, or fluid overpressure. Similar processes have been suggested for the development of large seafloor sulfide deposits (e.g., Embley et al., 1988; Fouquet et al., in press) and fossil VMS deposits on land (e.g., Lydon, 1984; Watkinson et al., 1990).

Systematic variation in the sulfur-isotopic composition of sulfides within the mound suggests mixing between isotopically distinct hydrothermal fluids. The main component is an end-member hydrothermal fluid with a deep hydrothermal source isotope composition of approximately $+5.5 \%$. A second fluid with a composition of approximately $+9.0 \%$ is generated in a shallow subsurface circulation system around the stockwork feeder zone. Entrainment of seawater from regions of low-temperature altered basalt, heating, and interaction with end-member fluid permeating out from the main feeder zone provide the conditions for basalt alteration and sulfate reduction at depth of $50 \mathrm{mbsf}$ to deeper than $120 \mathrm{mbsf}$. The possibility of sulfate reduction within the mound might also act to modify the isotopic composition of hydrothermal fluids circulating within the mound.

\section{ACKNOWLEDGMENTS}

The work presented here developed through discussions with the Leg 158 scientific party, both during and after the cruise. RK thanks Meg Tivey and Jeff Alt for the loan of additional polished thin sections. We also thank Pat Shanks, who revealed unpublished isotope analyses of surface samples and vent fluids sampled in 1985 from TAG. I. Jonasson, P. Nehlig, and R. Zierenberg each provided a detailed and constructive review. This study was supported by a research fellowship to R.K. from the European Hydrothermal Circulation and Ore Deposition (HYCOD) network.

\section{REFERENCES}

Alt, J.C., 1988. The chemistry and sulfur isotope composition of massive sulfide and associated deposits on Green Seamount, Eastern Pacific. Econ. Geol., 83:1026-1033.

1994. A sulfur isotopic profile through the Troodos ophiolite, Cyprus: primary composition and the effects of seawater hydrothermal alteration. Geochim. Cosmochim. Acta, 58:1825-1840.

Alt, J.C., Anderson, T.F., and Bonnell, L., 1989. The geochemistry of sulfur in a $1.3 \mathrm{~km}$ section of hydrothermally altered oceanic crust, DSDP Hole 504B. Geochim. Cosmochim. Acta, 53:1011-1023.

Arnold, M., and Sheppard, S.M.F., 1981. East Pacific Rise at latitude $21^{\circ} \mathrm{N}$ : isotopic composition and origin of the hydrothermal sulfur. Earth Planet. Sci. Lett. 56:148-156.

Auclair, G., Fouquet, Y., and Bohn, M., 1987. Distribution of selenium in high-temperature hydrothermal sulfide deposits at $13^{\circ} \mathrm{N}$, East Pacific Rise. Can. Mineral., 25:577-588.

Barton, P.B., Jr., and Bethke, P.M., 1987. Chalcopyrite disease in sphalerite: pathology and epidemiology. Am. Mineral., 72:451-467.

Becker, K., and Von Herzen, R.P., 1996. Pre-drilling observations of conductive heat flow at the TAG active mound using Alvin. In Humphris, S.E., Herzig, P.M., Miller, D.J., et al., Proc. ODP, Init. Repts., 158: College Station, TX (Ocean Drilling Program), 23-29.

Bluth, G.J., and Ohmoto, H., 1988. Sulfide-sulfate chimneys on the East Pacific Rise, $11^{\circ}$ and $13^{\circ} \mathrm{N}$ latitude. Part II: sulfur isotopes. Can. Mineral., 26:505-515.

Bowers, T.S., 1989. Stable isotope signatures of water-rock interaction in mid-ocean ridge hydrothermal systems: sulfur, oxygen, and hydrogen. $J$. Geophys. Res., 94:5775-5786.

Bralia, A., Sabatini, G., and Troja, F., 1979. A revaluation of the $\mathrm{Co} / \mathrm{Ni}$ ratio in pyrite: a geochemical tool in ore genesis problems. Mineral. Dep., 14:353-374.

Duckworth, R.C., Knott, R., Fallick, A.E., Rickard, D., Murton, B.J., and Van Dover, C., 1995. Mineralogy and sulfur isotope geochemistry of the Broken Spur sulfides, $29^{\circ} \mathrm{N}$, Mid-Atlantic Ridge. In Parson, L.M., Walker, C.L., and Dixon, D.R. (Eds.), Hydrothermal Vents and Processes. Geol. Soc. Spec. Publ. London, 87:175-189.

Edmond J.M., Campbell, A.C., Palmer, M.R., German, C.R., Klinkhammer, G.P., Edmonds, H.N., Elderfield, H., Thompson, G., and Rona, P., 1995. Time series studies of vent fluids from the TAG and MARK sites (1986, 1990): Mid-Atlantic Ridge: a new solution chemistry model and a mechanism for $\mathrm{Cu} / \mathrm{Zn}$ zonation in massive sulfide ore bodies. In Parson, L.M., Walker, C.L., and Dixon, D.R. (Eds.), Hydrothermal Vents and Processes. Geol. Soc. Spec. Publ. London, 87:77-86.

Embley, R.W., Jonasson, I.R., Perfit, M.R., Franklin, J.M., Tivey, M.A., Malahoff, A., Smith, M.F., and Francis, T.J.G., 1988. Submersible investigation of an extinct hydrothermal system on the Galapagos Ridge: sulfide mounds, stockwork zone, and differentiated lavas. Can. Mineral., 26:517-539.

Fouquet, Y., Auclair, G., Cambon, P., and Etoubleau, J., 1988. Geological setting, mineralogical and geochemical investigations on sulfide deposits near $13^{\circ} \mathrm{N}$ on the East Pacific Rise. Mar. Geol., 84:145-178.

Fouquet, Y., Knott, R., Cambon, P., Fallick, A., Rickard, D., and Desbruyeres, D., in press. Formation of large sulfide mineral deposits along fast spreading ridge: example from off axial deposits at $12^{\circ} 43^{\prime} \mathrm{N}$ on the East Pacific Rise. Earth Planet. Sci. Lett.

Fouquet, Y., Wafik, A., Cambon, P., Mevel, C., Meyer, G., and Gente, P., 1993. Tectonic setting and mineralogical and geochemical zonation in the Snakepit sulphide deposit (Mid-Atlantic Ridge at $23^{\circ} \mathrm{N}$ ). Econ. Geol., 88:2018-2036.

Graham, U.M., Bluth, G.J., and Ohmoto, H., 1988. Sulfide-sulfate chimneys on the East Pacific Rise, $11^{\circ}$ and $13^{\circ} \mathrm{N}$ latitudes. Part I: mineralogy and paragenesis. Can. Mineral., 26:487-504.

Hall, G.E.M., Pelchat, J.C., and Loop, J., 1988. Separation and recovery of various sulfur species in sedimentary rocks for stable isotopic determination. Chem. Geol., 67:35-45. 
Hannington, M.D., Herzig, P.M., Scott, S.D., Thompson, G., and Rona, P.A., 1991. Comparative mineralogy and geochemistry of gold-bearing sulfide deposits on the mid-ocean ridges. Mar. Geol., 101:217-248.

Hannington, M.D., and Scott, S.D., 1988. Mineralogy and geochemistry of an hydrothermal silica-sulfide-sulfate spire in the caldera of Axial-Seamount, Juan de Fuca Ridge. Can. Mineral., 26:603-625.

Hannington, M.D., Thompson, G., Rona, P.A., and Scott, S.D., 1988. Gold and native copper in supergene sulfides from the Mid-Atlantic Ridge. Nature, 333:64-66.

Hannington, M.D., Tivey, M.K., Larocque, A.C.L., Petersen, S., and Rona, P.A., 1995. The occurrence of gold in sulfide deposits of the TAG hydrothermal field, Mid-Atlantic Ridge. Can. Mineral., 33:1285-1310.

Hekinian, R., Fevrier, M., Bischoff, J.L., Picot, P., and Shanks, W.C., 1980. Sulfide deposits from the East Pacific Rise near $21^{\circ} \mathrm{N}$. Science, 207:1433-1444.

Humphris, S.E., Herzig, P.M., Miller, D.J., et al., 1996. Proc. ODP, Init. Repts., 158: College Station, TX (Ocean Drilling Program).

Humphris, S.E., Herzig, P.M., Miller, D.J., Alt, J.C., Becker, K., Brown, D., Brügmann, G., Chiba, H., Fouquet, Y., Gemmell, J.B., Guerin, G., Hannington, M.D., Holm, N.G., Honnorez, J.J., Itturino, G.J., Knott, R., Ludwig, R., Nakamura, K., Petersen, S., Reysenbach, A.-L., Rona, P.A., Smith, S., Sturz, A.A., Tivey, M.K., and Zhao, X., 1995. The internal structure of an active sea-floor massive sulphide deposit. Nature, 377:713-716.

Huston, D.L., Sie, S.H., Suter, G.F., Cooke, D.R., and Both, R.A., 1995. Trace elements in sulfide minerals from Eastern Australia volcanichosted massive sulfide deposits: Part I. Proton microprobe analyses of pyrite, chalcopyrite and sphalerite, and Part II. Selenium levels in pyrite: Comparisons with $\delta^{34} S$ values and implications for the source of sulfur in volcanogenic hydrothermal systems. Econ. Geol., 90:1167-1196.

Hutchinson, R.W., and Searle, D.L., 1971. Stratabound pyrite deposits in Cyprus and relations to other sulfide ores. Soc. Min. Geol. Jpn. Spec. Iss., 3:198-205

Janecky, D.R., and Shanks, W.C., III, 1988. Computational modeling of chemical and sulfur isotopic reaction processes in seafloor hydrothermal systems: chimneys, massive sulfides, and subjacent alteration zones. Can. Mineral., 26:805-825.

Johnson, A.E., 1972. Origin of Cyprus pyrite deposits. 24th Int. Geol. Congr., 291-298.

Kase, K., Yamamoto, M., and Shibata, T., 1990. Copper-rich sulfide deposit near $23^{\circ} \mathrm{N}$, Mid-Atlantic Ridge: chemical composition, mineral chemistry, and sulfur isotopes. In Detrick, R., Honnorez, J., Bryan, W.B., Juteau, T., et al. Proc. ODP, Sci. Results, 106/109: College Station, TX (Ocean Drilling Program), 163-177.

Kissin, S.A., and Scott, S.D., 1982. Phase relations involving pyrrhotite below $350^{\circ}$ C. Econ. Geol., 77:1739-1754.

Kleinrock, M.C., Humphris, S.E., and the Deep-TAG Team, 1996. Detailed structure and morphology of the TAG active hydrothermal mound and its geotectonic environment. In Humphris, S.E., Herzig, P.M., Miller, D.J., et al., Proc. ODP, Init. Repts., 158: College Station, TX (Ocean Drilling Program), 15-21.

Knott, R., Bäcker, H., Fallick, A.E., and Rickard, D., 1995. Mineralogy and sulfur isotopic characteristics of a massive sulfide boulder, Galapagos Rift $85^{\circ} 55^{\prime}$ W. In Parson, L.M., Walker, C.L., and Dixon, D.R. (Eds.), Hydrothermal Vents and Processes. Geol. Soc. Spec. Publ. London, 87:207-222.

Kojima, S., and Sugaki, A., 1985. Phase relations in the Cu-Fe-Zn-S system between $500^{\circ}$ and $300^{\circ} \mathrm{C}$ under hydrothermal conditions. Econ. Geol., 80:158-171.

Koski, R.A., Jonasson, I.R., Kadko, D.C., Smith, V.K., and Wong, F.L., 1994. Compositions, growth mechanisms, and temporal relations of hydrothermal sulfide-sulfate-silica chimneys at the northern Cleft segment, Juan de Fuca Ridge. J. Geophys. Res., 99:4813-4832.

Lafitte, R., and Maury, R., 1983. The stoichiometry of sulfides and its evolution: a chemical study of pyrites, chalcopyrites and sphalerites from terrestrial and oceanic environments. Earth Planet. Sci. Lett., 64:145-152.

Lalou, C., Reyss, J.L., Brichet, E., Arnold, M., Thompson, G., Fouquet, Y., and Rona, P.A., 1993. New age data for Mid-Atlantic Ridge hydrothermal sites: TAG and Snakepit geochronology revisited. J. Geophys. Res., 98:9705-9713.
Lalou, C., Thompson, G., Arnold, M., Brichet, E., Druffel, E., and Rona, P.A., 1990. Geochronology of TAG and Snakepit hydrothermal fields, Mid-Atlantic Ridge: witness to a long and complex hydrothermal history. Earth Planet. Sci. Lett., 97:113-128.

Lein, A.Y., Ul'yanova, N.V., Grinenko, V.A., and Lisitsyn, A.P., 1991. Geochemistry of the hydrothermal sulfide ores of the Mid-Atlantic Ridge $\left(26^{\circ} \mathrm{N}\right)$. Geochem. Int., $28: 1-13$.

Lydon, J.W., 1984. Some observations on the morphology and ore textures of volcanogenic sulfide deposits of Cyprus. Pap.-Geol. Surv. Can., 841A:601-610.

Marchig, V., Puchelt, H., Rosch, H., and Blum, N., 1990. Massive sulfides from ultra-fast spreading Ridge, East Pacific Rise at $18-21^{\circ} \mathrm{S}$ : a geochemical stock report. Mar. Min., 9:459-493.

Masuda, H., Chiba, H., Gamo, T., Fujioka K., and Nakamura, M., 1995. Distribution and chemical characteristics of hydrothermal alteration minerals recovered from the TAG active mound, MAR $26^{\circ} \mathrm{N}$. JAMSTEC J. Deep Sea Res., 11:111-124.

Murowchick, J.B., 1992. Marcasite inversion and the petrographic determination of pyrite ancestry. Econ. Geol., 87:1141-1152.

Murowchick, J.B., and Barnes, H.L., 1986. Marcasite precipitation from hydrothermal solutions. Geochim. Cosmochim. Acta, 50:2615-2629.

Oehler, J.H., 1976. Hydrothermal crystallization of silica gel. Geol. Soc. Am. Bull., 87:1143-1152.

Oudin, E., Picot, P., and Pouit, G., 1981. Comparison of sulfide deposits from the East Pacific Rise and Cyprus. Nature, 291:404-407.

Rees, C.E., Jenkins, W.J., and Monster, J., 1978. The sulphur isotopic composition of ocean water sulphate. Geochim. Cosmochim. Acta, 42:377381.

Rona, P.A., Bogdanov, Y.A., Gurvich, E.G., Rimski-Kursakov, A., Sagalevitch, A.M., Hannington, M.D., and Thompson, G., 1993a. Relict hydrothermal zones in the TAG hydrothermal field, Mid-Atlantic Ridge $26^{\circ} \mathrm{N}$, $45^{\circ}$ W. J. Geophys. Res., 98:9715-9730.

Rona, P.A., Hannington, M.D., Raman, C.V., Thompson, G., Tivey, M.K., Humphris, S.E., Lalou, C., and Petersen, S., 1993b. Active and relict seafloor hydrothermal mineralization at the TAG hydrothermal field, MidAtlantic Ridge. Econ. Geol., 88:1987-2013.

Sakai, H., Des Marais, D.J., Ueda, A., and Moore, J.G., 1984. Concentrations and isotope ratios of carbon, nitrogen and sulfur in ocean-floor basalts. Geochim. Cosmochim. Acta, 48:2433-2441.

Scott, S.D., Chase, R.L., Hannington, M.D., Michael, P.J., McConachy, T.F., and Shea, G.T., 1990. Sulfide deposits, tectonics, and petrogenesis of southern Explorer Ridge, northeast Pacific Ocean. In Malpas, J., Moores, E.M., Panayiotou, A., and Xenophontos, C. (Eds.), Ophiolites: Ocean Crustal Analogues. Proc. Symp. "Troodos 1987,” 719-733.

Shanks, W.C., III, Bischoff, J.L., and Rosenbauer, R.J., 1981. Seawater sulfate reduction and sulfur isotope fractionation in basaltic systems: interaction of seawater with fayalite and magnetite at $200-350^{\circ} \mathrm{C}$. Geochim. Cosmochim. Acta, 45:1977-1995.

Shanks, W.C., III, and Seyfried, W.E., Jr., 1987. Stable isotope studies of vent fluids and chimney minerals, southern Juan de Fuca Ridge: sodium metasomatism and seawater sulfate reduction. J. Geophys. Res., 92:11387-11399.

Shipboard Scientific Party, 1996. Explanatory notes. In Humphris, S.E., Herzig, P.M., Miller, D.J., et al., Proc. ODP, Init. Repts., 158: College Station, TX (Ocean Drilling Program), 37-54.

Thompson, G., Humphris, S.E., Schroeder, B., Sulanowska, M., and Rona, P.A., 1988. Active vents and massive sulfides at $26^{\circ} \mathrm{N}$ (TAG) and $23^{\circ} \mathrm{N}$ (Snakepit) on the Mid-Atlantic Ridge. Can. Mineral., 26:697-711.

Thompson, G., Mottl, M.J., and Rona, P.A., 1985. Morphology, mineralogy, and chemistry of hydrothermal deposits from the TAG area, $26^{\circ} \mathrm{N}$ MidAtlantic Ridge. Chem. Geol., 49:243-257.

Tivey, M.K., Humphris, S.E., Thompson, G., Hannington, M.D., and Rona, P.A., 1995. Deducing patterns of fluid flow and mixing within the TAG active hydrothermal mound using mineralogical and geochemical data. $J$. Geophys. Res., 100:12527-12555.

Ueda, A., and Krouse, H.R., 1986. Direct conversion of sulfide and sulfate minerals to $\mathrm{SO}_{2}$ for isotope analyses. Geochem. J., 20:209-212.

Watkinson, D.H., McEwan, J., and Jonasson, I.R., 1990. Mine Gallen, Noranda, Quebec: geology of an Archean massive sulphide mound. In 
Rive, M., et al. (Eds.), The Northwest Quebec Polymetallic Belt. Can. Inst. Mining Metall., Spec. Vol. 43:167-174.

Woodruff, L.G., and Shanks, W.C., 1988. Sulfur isotope study of chimney minerals and hydrothermal fluids from $21^{\circ} \mathrm{N}$, East Pacific Rise: hydrothermal sulfur sources and disequilibrium sulfate reduction. J. Geophys. Res., 93:4562-4572.

Zierenberg, R.A., Shanks, W.C., III., and Bischoff, J.L., 1984. Massive sulfide deposits at $21^{\circ}$, East Pacific Rise: chemical composition, stable isotopes, and phase equilibria. Geol. Soc. Am. Bull., 95:922-929.
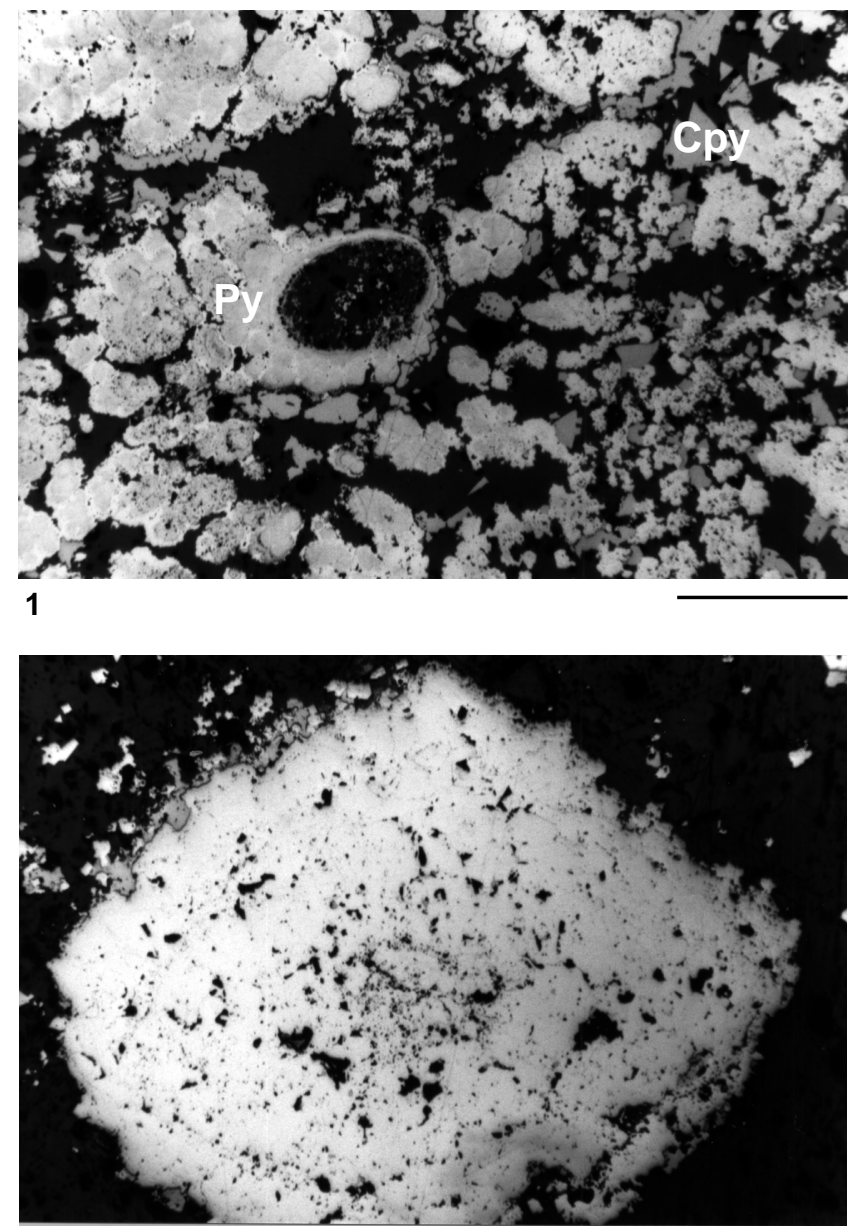

3

Plate 1. Microscale textures in porous sulfide and massive pyrite clasts. 1. Porous Fe-Cu sulfide. Fine-grained colloform pyrite aggregates (labeled Py) preserve tubular biogenic structure and form a porous framework. Later overgrowth of bladed chalcopyrite (labeled Cpy) in vugs. Black areas are pore spaces. Reflected light photomicrograph, scale bar $500 \mu \mathrm{m}$. 2. Pyrite-anhydrite breccia. Aggregate of microcrystalline pyrite (Py1) in anhydrite matrix (dark gray). The remainder of the matrix contains coarser grained euhedral pyrite (Py2) with chalcopyrite overgrowth. A clast of coarse polycrystalline pyrite (Py3) contains quartz inclusions. Reflected light photomicrograph, scale bar $500 \mu \mathrm{m}$. 3. Pyrite-anhydrite breccia. Pyrite clast showing a microporous core surrounded by polycrystalline pyrite. Faint traces of sequential overgrowth layers are visible. Reflected light photomicrograph, scale bar $500 \mu \mathrm{m}$. 4. Pyrite-anhydrite breccia. Irregular pyrite clast formed by the overgrowth of euhedral pyrite with zones of chalcopyrite inclusions (arrow) distributed on growth layers. Note the large quartz grain in the core of the clast (black). Reflected light photomicrograph, scale bar $=500 \mu \mathrm{m}$
Date of initial receipt: 8 July 1996

Date of acceptance: 17 March 1997

Ms 158SR-201
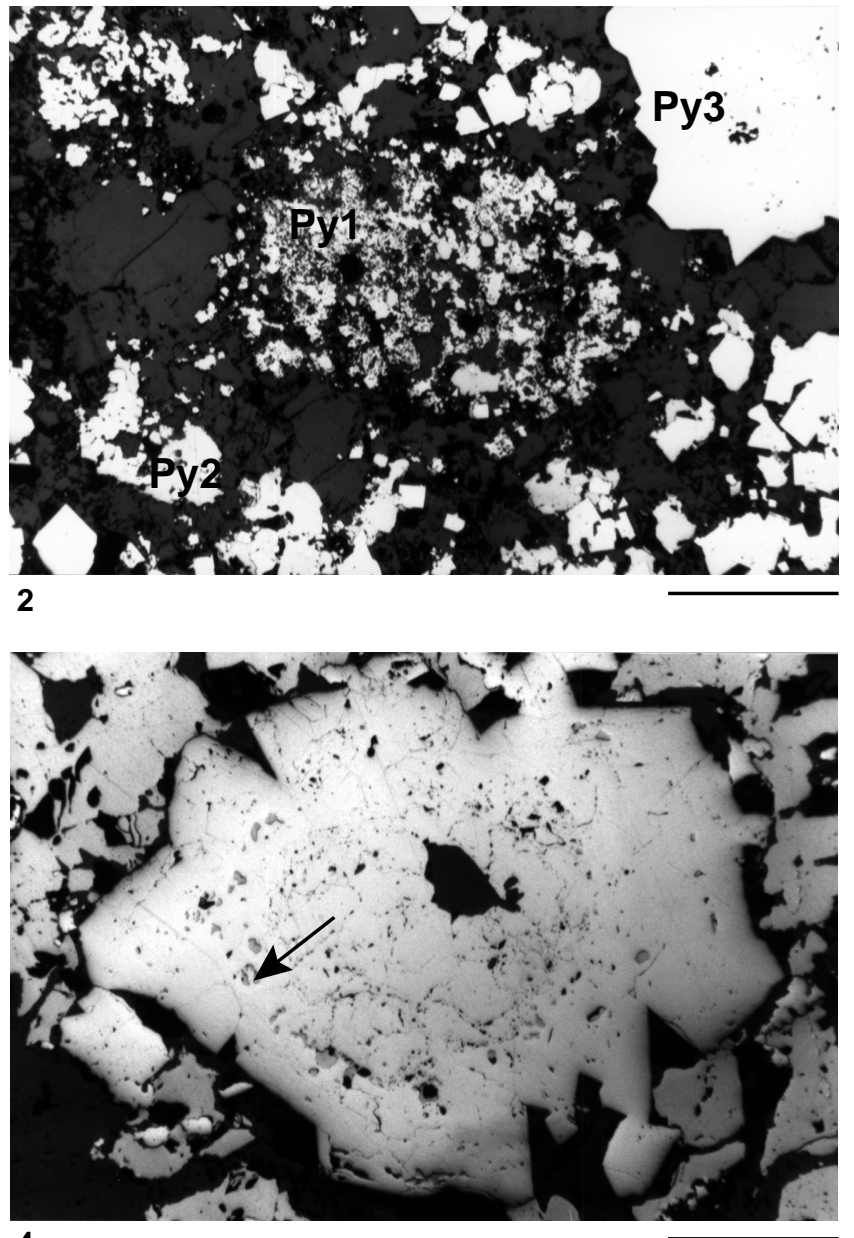

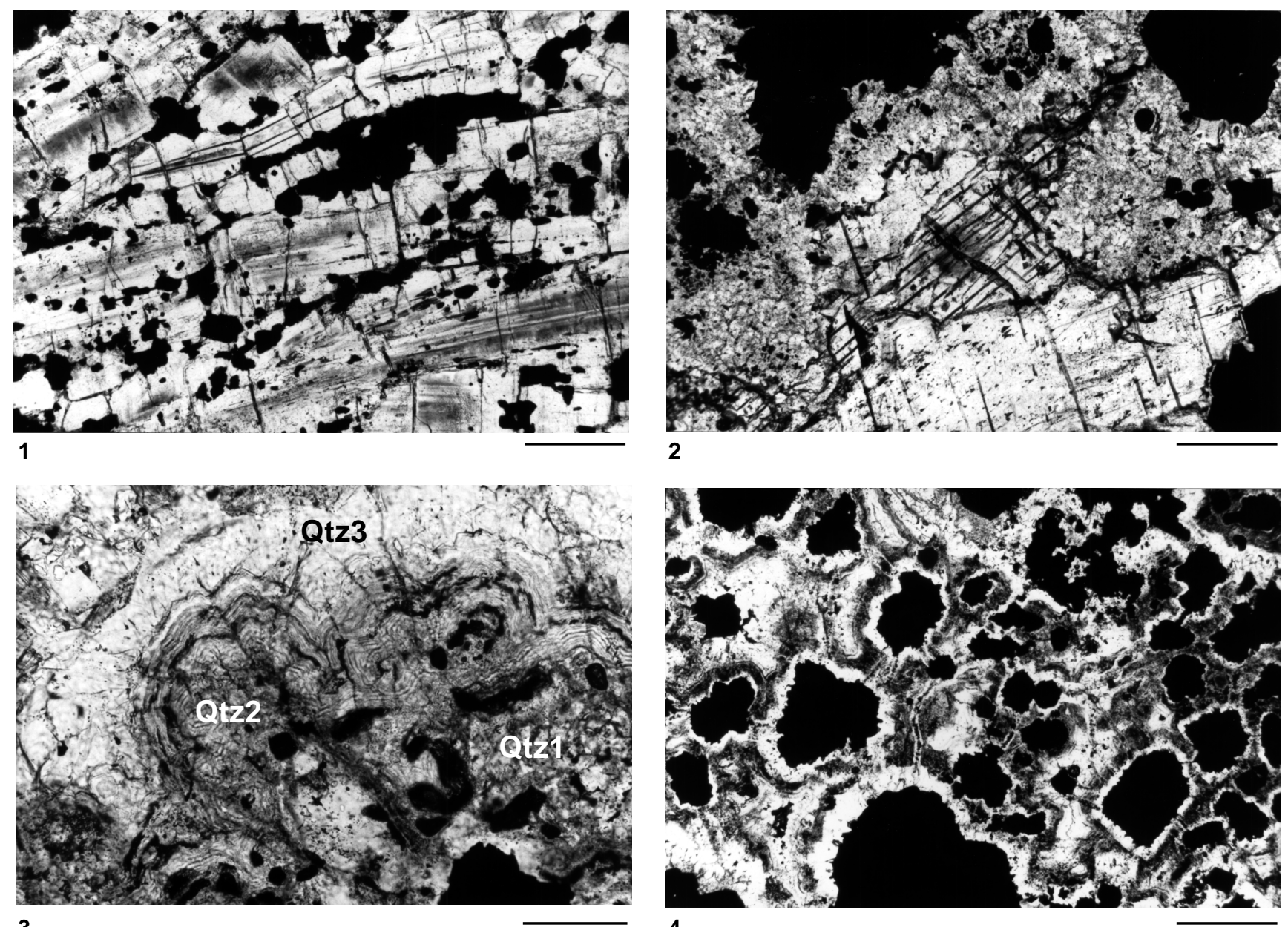

3

4

Plate 2. Microscale textures of anhydrite and quartz in the breccia matrix. 1. Pyrite-anhydrite breccia. Pyrite and chalcopyrite (black) distributed along the grain boundaries of coarse anhydrite crystals. Transmitted light photomicrograph, scale bar $500 \mu \mathrm{m}$. 2. Transitional pyrite-quartz-anhydrite breccia. Replacement of anhydrite (transparent, cleavage) by microcrystalline quartz aggregates (dusty gray). The quartz appears to have nucleated on (and possibly replaced) the pyrite (black). Transmitted light photomicrograph, scale bar $500 \mu \mathrm{m}$. 3. Pyrite-quartz breccia. Microcrystalline quartz (Qtz1) with disseminated pyrite inclusions is overgrown by generations of banded quartz (Qtz2). This is transitional to coarse-grained, clear quartz (Qtz3) which projects into vugs (e.g., top left-hand corner). Transmitted light photomicrograph, scale bar $200 \mu \mathrm{m}$. 4. Pyrite-quartz breccia. Dusty (gray) microcrystalline quartz with traces of banding. Halos of clear, coarser grained quartz develop around pyrite grains and aggregates by replacement of pyrite grains. Note the empirical relationship between the width of the halo and the size of the pyrite aggregate. The cause of this is uncertain. Transmitted light photomicrograph, scale bar $=500 \mu \mathrm{m}$. 